\title{
Global energy efficiency improvement in the long term: a demand- and supply-side perspective
}

\author{
Wina Graus • Eliane Blomen • Ernst Worrell
}

Received: 16 March 2010 /Accepted: 18 October 2010/Published online: 4 November 2010

(C) The Author(s) 2010. This article is published with open access at Springerlink.com

\begin{abstract}
This study assessed technical potentials for energy efficiency improvement in 2050 in a global context. The reference scenario is based on the World Energy Outlook of the International Energy Agency 2007 edition and assumptions regarding gross domestic product developments after 2030. In the reference scenario, worldwide final energy demand almost doubles from $293 \mathrm{EJ}$ in 2005 to $571 \mathrm{EJ}$ in 2050 and primary energy supply increases from 439 EJ in 2005 to $867 \mathrm{EJ}$ in 2050 (excluding non-energy use). It is estimated that, by exploiting the technical potential for energy efficiency improvement in energy demand sectors, this growth can be limited to $8 \%$ or 317 EJ final energy demand and 473 EJ primary energy supply in 2050. This corresponds to a potential for demand-side energy efficiency improvement of $44 \%$ in 2050, in comparison to reference energy use. In addition, a potential exists for improving energy efficiency in the transformation sector. In 2005, as much as $33 \%$ of primary energy supply is lost in the transformation and distribution of primary energy. It
\end{abstract}

W. Graus $(\bowtie) \cdot$ E. Worrell

Copernicus Institute of Sustainable Development,

Utrecht University,

Heidelberglaan 2,

3584 CS Utrecht, The Netherlands

e-mail: w.graus@geo.uu.nl

E. Blomen

Ecofys Netherlands BV,

Kanaalweg 16-G,

3526 KL Utrecht, The Netherlands is estimated that this share can be reduced to $19 \%$ in 2050 by, e.g. improving energy efficiency of fossilfired power generation (assuming no changes in the fuel mix for power generation). Including the potential for energy efficiency improvement in energy demand sectors, total primary energy supply would then decrease by $10 \%$ from 439 EJ in 2005 to 393 EJ in 2050. This contributes to a total potential for energy efficiency improvement of 55\% in 2050 in comparison to reference primary energy supply.

Keywords Energy efficiency · Global energy use · Energy scenario

\section{Introduction}

In the period 1990-2005 global primary energy supply increased by $30 \%$ from 367 to 479 EJ. In the reference scenario of the IEA World Energy Outlook 2007 edition, global energy supply grows by another $55 \%$ to 742 EJ in 2030 (IEA 2007a). Fossil fuels account for $80 \%$ of primary energy supply in 2005 and are expected to have the same share in energy supply in 2030, under business as usual conditions. Fossil fuel combustion is a major source for greenhouse gas emissions and accounts for $75 \%$ of total greenhouse gas emissions in 2005 (WRI 2008). Energy efficiency is a key measure to reduce fossil fuel consumption and thereby greenhouse gas emissions. Assumptions regarding the potential for energy 
efficiency improvement are therefore an important input in long-term energy and greenhouse gas emission scenarios (e.g. IPPC (2007), IEA (2008a) and WBCSD (2005)). Few studies are however available that give details on the potential for energy efficiency improvement, in a global context, while looking at both energy demand and energy supply sectors.

The goal of this study is to estimate global energy efficiency potentials for energy demand and supply sectors for the period 2005-2050, based on available literature sources and own calculations. It is based on scenario studies done for UBA (2010) and for the Greenpeace-EREC Energy [r] evolution study (see Krewitt et al. 2007 and 2009), where it is assumed that a certain percentage of the technical potentials are implemented in the Energy [R]evolution scenario.

A number of global energy scenarios are used as inputs to determine technical potentials. These are, e.g. IEA's Energy Technology Perspectives (IEA ETP 2008) and the World Business Council on Sustainable Development's scenario for 2050 (WBCSD 2005). The IEA ETP developed several scenarios for reducing greenhouse gas emissions. One of them is the BLUE Map scenario, in which specific measures to improve energy efficiency are looked at in terms of market share and percentage of improvement in 2050.

This paper is structured as follows. First, the approach and data sources are described in the 'Approach and data sources' section followed by the results in the 'Results' section. The 'Discussion of uncertainties' section gives a discussion of uncertainties and the 'Conclusions' section presents conclusions.

\section{Approach and data sources}

This section describes the approach used to calculate the technical potentials for energy efficiency improvement. This is defined as the energy use that can be reduced by implementing technical measures, in comparison to the level of energy use in a reference scenario, where current trends continue and no large changes take place in the production and consumption structure of the economy. Measures aimed at influencing behavioural change are not taken into account. This section first gives a description of the reference scenario ('Reference scenario' section) followed by a description of the method used for calculating technical potentials ('Technical potentials' section).

\section{Reference scenario}

The reference scenario is based on the World Energy Outlook (WEO) of the International Energy Agency edition 2007 (IEA 2007a), for the period 2005-2030. For the period 2030-2050, the WEO scenario is extended by gross domestic product (GDP) forecasts from Simon et al. (2008). The economic growth assumptions are summarised in Table 1. Under the reference scenario, global GDP grows by $440 \%$ from US $\$ 63,720$ billion in 2005 to US $\$ 279,100$ billion in 2050 (in 2006 dollars, PPP). Population increases from 6.5 billion in 2005 to 9.2 billion in 2050 .

The regional disaggregation in this study is the same as the one used in the WEO 2007 edition; OECD Europe, OECD North America, OECD Pacific, transition economies, China, India, rest of developing
Table 1 GDP development projections (average annual growth rates; 2010-2030: IEA (2007a) and 20302050: Simon et al. (2008))

\begin{tabular}{lcccccc}
\hline & 2010 & 2015 & 2020 & 2030 & 2040 & 2050 \\
\hline OECD Europe & $2.6 \%$ & $2.2 \%$ & $2.0 \%$ & $1.7 \%$ & $1.3 \%$ & $1.1 \%$ \\
OECD North America & $2.7 \%$ & $2.6 \%$ & $2.3 \%$ & $2.2 \%$ & $2.0 \%$ & $1.8 \%$ \\
OECD Pacific & $2.5 \%$ & $1.9 \%$ & $1.7 \%$ & $1.5 \%$ & $1.3 \%$ & $1.2 \%$ \\
Transition economies & $5.6 \%$ & $3.8 \%$ & $3.3 \%$ & $2.7 \%$ & $2.5 \%$ & $2.4 \%$ \\
India & $8.0 \%$ & $6.4 \%$ & $5.9 \%$ & $5.7 \%$ & $5.4 \%$ & $5.0 \%$ \\
China & $9.2 \%$ & $6.2 \%$ & $5.1 \%$ & $4.7 \%$ & $4.2 \%$ & $3.6 \%$ \\
Rest of developing Asia & $5.1 \%$ & $4.1 \%$ & $3.6 \%$ & $3.1 \%$ & $2.7 \%$ & $2.4 \%$ \\
Latin America & $4.3 \%$ & $3.3 \%$ & $3.0 \%$ & $2.8 \%$ & $2.6 \%$ & $2.4 \%$ \\
Africa & $5.0 \%$ & $4.0 \%$ & $3.8 \%$ & $3.5 \%$ & $3.2 \%$ & $3.0 \%$ \\
Middle East & $5.1 \%$ & $4.6 \%$ & $3.7 \%$ & $3.2 \%$ & $2.9 \%$ & $2.6 \%$ \\
World & $4.6 \%$ & $3.8 \%$ & $3.4 \%$ & $3.2 \%$ & $3.0 \%$ & $2.9 \%$ \\
\hline
\end{tabular}


Asia, Latin America, Africa and Middle East (see IEA 2007a).

In this study, we first look at the growth of final energy demand and secondly at the development of primary energy supply. Final energy demand (shortly energy demand) is defined as energy use by end use sectors (industry, transport, buildings and others) either in the form of electricity or in the form of heat or fuels. Primary energy supply (shortly energy supply) is defined as primary energy supplied by supply sectors (e.g. power generation, energy distribution companies and refineries) to end use sectors. The losses that occur in energy supply are here called transformation losses and include distribution losses. By first looking at energy demand, the lowest possible energy use can be calculated in 2050 by implementing both technical measures in energy demand sectors and energy supply sectors.

The growth of energy demand as a result of GDP growth depends on the development of the energy intensity of the economy. Energy intensity is in this study defined as final energy use per unit of gross domestic product. The energy intensity in an economy tends to decrease over time. Changes in energy intensity can be a result of a number of factors, e.g.:

$\triangleright$ Autonomous energy efficiency improvement, which occurs due to technological developments. Each new generation of capital goods is likely to be more energy efficient than the one before.
$>$ Policy-induced energy efficiency improvement as a result of which economic actors change their behaviour and invest in more energy efficient technologies or improve energy management.

$>$ Structural changes that can have a downward or upward effect on the economy's energy intensity. An example of a downward effect is a shift in the economy away from energy-intensive industrial activities to service-related activities. Also there can be demand saturation in certain sectors or countries. For instance, in a country with already comparatively high volumes of passenger travel, the increase of GDP may lead to a lower than linear increase of passenger travel and thereby decreasing energy intensity.

Only the first two are regarded in this study as energy efficiency improvement. Energy efficiency improvement is defined as the decrease in specific energy consumption per physical unit of energy service (e.g. GJ/tonne crude steel, $\mathrm{MJ} /$ passenger-km, $\mathrm{MJ} / \mathrm{m}^{2}$ floor surface, etc.).

For the calculation of the technical potentials, it is important to know the energy intensity decrease in the reference scenario that is a result of energy efficiency improvement and the energy intensity decrease that results from structural changes. The energy intensity decrease in the reference scenario differs per region, ranging from $1 \%$ to $2.5 \%$ per year as average, for the period 2005-2050 (see Fig. 1).
Fig. 1 Growth final energy demand in average \% per year in period 2005-2050. Data for period 2005-2030 is based on IEA (2007a) and data for period 2030-2050 is extrapolated based on trend energy intensity in period 2005-2030 and GDP growth rates of Simon et al. (2008)

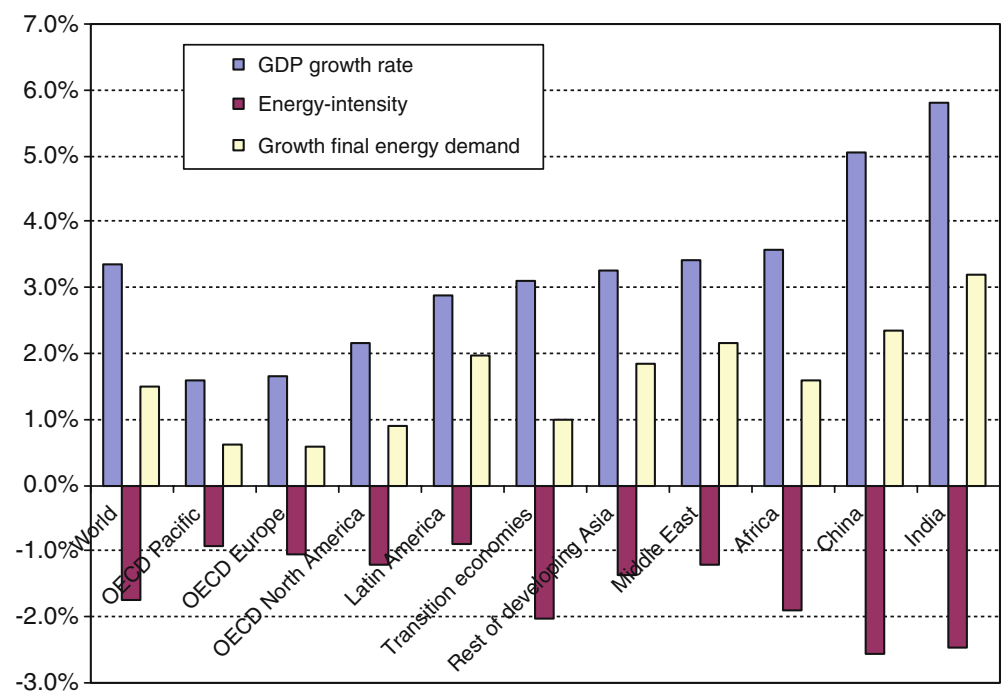


The share of energy intensity decrease due to autonomous or policy-induced energy efficiency improvement is not available for this study, except for transport (see also the 'Transport' and 'Discussion of uncertainties' sections). For sectors other than transport, we assume that autonomous and policy-induced energy efficiency improvement is equal to $1 \%$ per year, based on historical developments of energy efficiency improvement in buildings and industries (see, e.g. Blok (2005) and Odyssee (2005)). When calculating the potential for energy efficiency improvement, the energy efficiency that already occurs in the reference scenario is subtracted from the total potential in order to calculate the remaining potential relative to the reference scenario. More detailed explanations are included in the 'Technical potentials' section.

Figure 1 shows annual GDP growth rates, annual energy intensity decrease and the resulting annual growth in final energy demand per region in the reference scenario. Global energy intensity decreases from $4.6 \mathrm{MJ} / \mathrm{US} \$$ to $2.0 \mathrm{MJ} / \mathrm{US} \$$ in the period $2005-$ 2050 (or $1.8 \%$ per year).

Final energy demand is projected to increase most in India and China $(3.2 \%$ and $2.4 \%$ per year, respectively), followed by Middle East $(2.2 \%$ per year) and Latin America (2.0\% per year). Energy demand increase is lowest in OECD Europe, OECD Pacific and OECD North America (between 0.6\% and $0.9 \%$ per year), due to lower GDP growth rates.

The reference scenario covers energy use of four sectors: (1) transport, (2) industry, (3) buildings and others (e.g. agriculture) and (4) transformation sector. Per sector, a distinction is made between electricity demand and fuel and heat demand. Fuel and heat demand is shortly referred to as fuel demand. This study only focuses on energy-related fuel, power and heat use. Non-energy use (including feedstock use in petrochemical industry) is excluded. It is assumed that the share of non-energy use in industries in 2050 is the same as in 2030 .

Figure 2 shows the reference scenario for final energy demand for the world by sector.

Global final energy demand is expected to grow by 95\%, from $293 \mathrm{EJ}$ in 2005 to $571 \mathrm{EJ}$ in 2050 . The relative growth in the transport sector is largest, where energy demand is expected to grow from $84 \mathrm{EJ}$ in 2005 to $183 \mathrm{EJ}$ in 2050. Fuel demand in buildings and agriculture is expected to grow slowest from $91 \mathrm{EJ}$ in 2005 to $124 \mathrm{EJ}$ in 2050.

Figure 3 shows the final energy demand per region in the reference scenario.

In the reference scenario, final energy demand in 2050 is largest in China (121 EJ), followed by OECD North America (107 EJ) and OECD Europe (68 EJ). Final energy demand in OECD Pacific and Middle East is lowest (28 and $31 \mathrm{EJ}$, respectively).

Table 2 shows final energy demand, final energy demand per capita and primary energy supply by world region. Primary energy supply is based on the conversion efficiency (ratio: final energy demand/primary energy supply) of the transformation sector, which is also included in the table. The conversion efficiency is based on the development of the conversion efficiency in the period 2030-2050 in IEA (2007a).

In terms of final energy demand per capita, there are still large differences between world regions in
Fig. 2 Final energy demand $(\mathrm{EJ})$ in reference scenario per sector worldwide

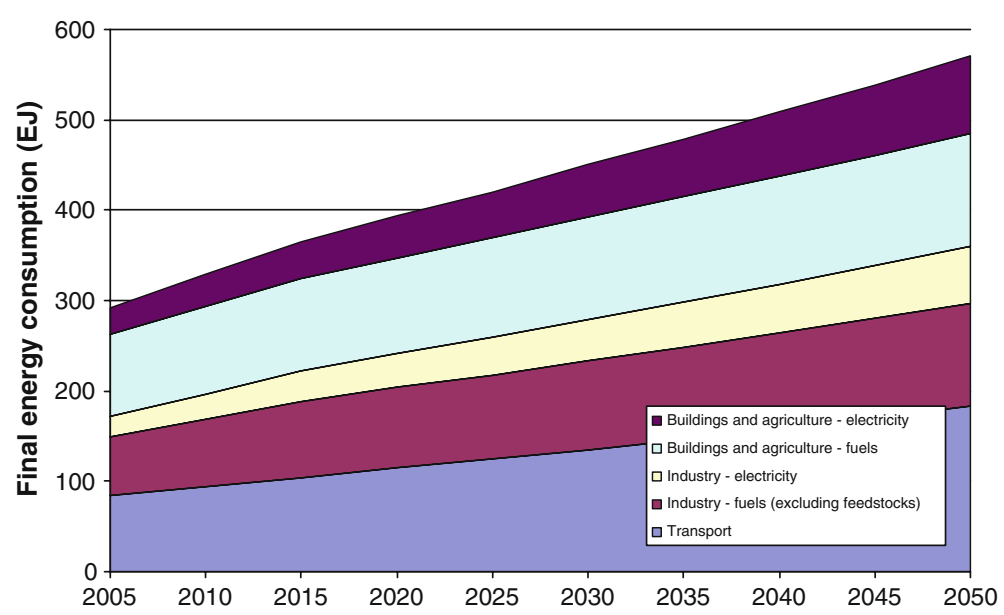


Fig. 3 Final energy demand $\mathrm{PJ})$ in reference scenario per region

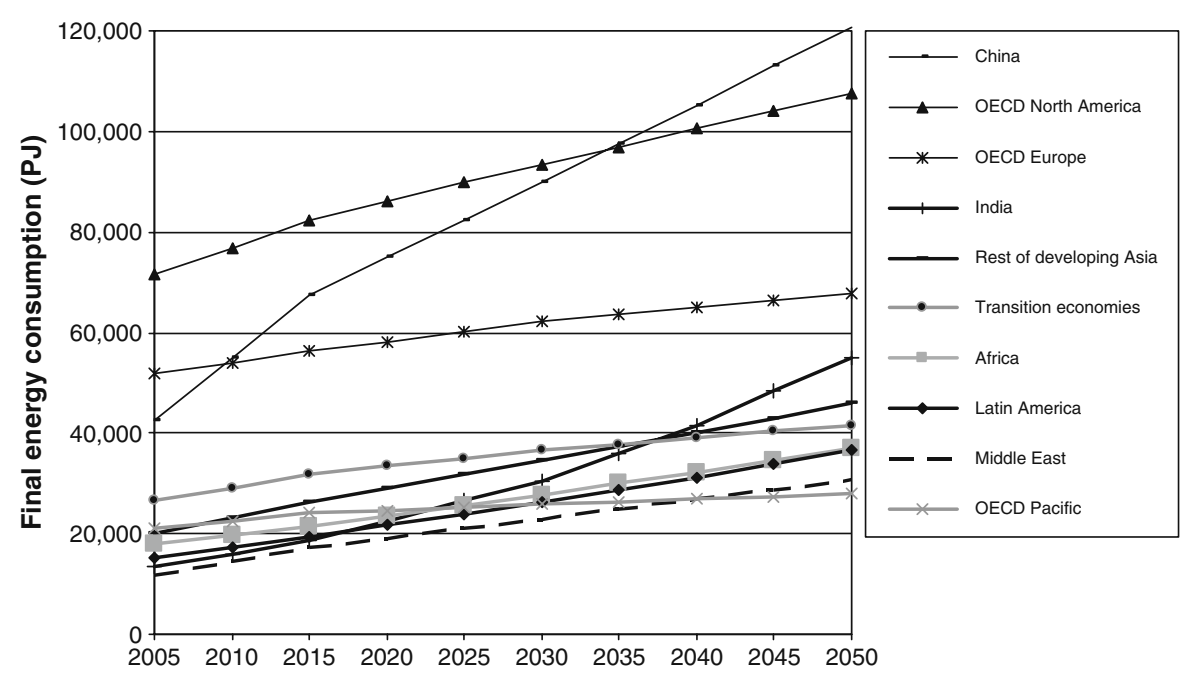

2050 in the reference scenario. Energy demand per capita is highest in OECD North America (186 GJ/capita), followed by OECD Pacific and transition economies (156 and $142 \mathrm{GJ} /$ capita, respectively). Final energy demand in Africa, rest of developing Asia, India and Latin America is expected to be lowest (19, 30, 33 and $58 \mathrm{GJ} /$ capita, respectively).

In the reference scenario, global primary energy supply grows from $439 \mathrm{PJ}$ in 2005 to $867 \mathrm{PJ}$ in 2050. Non-OECD countries show the strongest growth of primary energy supply from $218 \mathrm{PJ}$ in 2005 to $556 \mathrm{PJ}$ in 2050. Total energy supply in OECD countries grows from 214 to $299 \mathrm{EJ}$ in the same period. This means that the share of non-OECD countries in total primary energy use grows from $50 \%$ in 2005 to $71 \%$ in 2050 .

The conversion efficiency in 2005 ranges from $62 \%$ for China to $78 \%$ for Latin America, with a worldwide average of $67 \%$. The major share of transformation losses occur in the power generation sector. In 2005 , this corresponds globally to $80 \%$ of total transformation losses, including electricity transmission and distribution losses (based on IEA 2007b). The remaining transformation losses occur mainly in oil refining and coal transformation (e.g. coking). The low conversion efficiency for China is mainly a result of the large share of coal-fired power generation at

Table 2 Final energy demand and primary energy supply

\begin{tabular}{|c|c|c|c|c|c|c|c|c|}
\hline & \multicolumn{2}{|c|}{$\begin{array}{l}\text { Final energy } \\
\text { demand (EJ) }\end{array}$} & \multicolumn{2}{|c|}{$\begin{array}{l}\text { Final energy demand } \\
\text { (GJ/capita) }\end{array}$} & \multicolumn{2}{|c|}{$\begin{array}{l}\text { Primary energy } \\
\text { supply (EJ) }\end{array}$} & \multicolumn{2}{|c|}{$\begin{array}{l}\text { Conversion efficiency } \\
(\%)\end{array}$} \\
\hline & 2005 & 2050 & 2005 & 2050 & 2005 & 2050 & 2005 & 2050 \\
\hline OECD North America & 71 & 107 & 164 & 186 & 106 & 157 & $68 \%$ & $68 \%$ \\
\hline OECD Pacific & 21 & 28 & 105 & 156 & 32 & 43 & $66 \%$ & $64 \%$ \\
\hline OECD Europe & 52 & 68 & 97 & 120 & 72 & 89 & $72 \%$ & $76 \%$ \\
\hline Transition economies & 27 & 42 & 78 & 142 & 42 & 64 & $63 \%$ & $65 \%$ \\
\hline India & 13 & 55 & 12 & 33 & 21 & 92 & $64 \%$ & $60 \%$ \\
\hline China & 43 & 121 & 32 & 85 & 68 & 202 & $62 \%$ & $60 \%$ \\
\hline Rest of developing Asia & 20 & 46 & 21 & 30 & 28 & 66 & $72 \%$ & $70 \%$ \\
\hline Latin America & 15 & 37 & 34 & 58 & 20 & 48 & $78 \%$ & $76 \%$ \\
\hline Middle East & 12 & 31 & 63 & 89 & 18 & 49 & $65 \%$ & $63 \%$ \\
\hline Africa & 18 & 37 & 20 & 19 & 25 & 51 & $74 \%$ & $72 \%$ \\
\hline World & 293 & 571 & 45 & 62 & 439 & 867 & $67 \%$ & $66 \%$ \\
\hline
\end{tabular}


low efficiency. The relatively high efficiency for Latin America is mainly a result of a high share of hydropower in power generation. In IEA statistics, the conversion of electricity generated by hydropower to primary energy input is $100 \%$.

Technical potentials

The technical potential for energy efficiency improvement is calculated on basis of literature sources and own calculations. The potentials incorporate technical measures and do not include energy savings potentials by behavioural or organizational changes or structural changes (e.g. modal shift in transport). Besides current best practices also emerging technologies are taken into account as well as improved material efficiency. We assume that the measures can be implemented after 2010 and that equipment or installations are replaced at the end of their lifetime. More detailed assumptions are given in the following sections: 'Transport', 'Industry', 'Buildings and others' and 'Transformation sector'.

\section{Transport}

Data regarding energy use per transport mode are based on the WBCSD transport scenario (IEA/SMP
2004). This scenario is consistent with the IEA WEO 2007 in terms of global energy demand for transport in 2050 .

Transport accounts for nearly $30 \%$ of final energy demand worldwide, in 2006 (IEA 2007b). For most regions, the share of transport in energy demand is expected to increase by 2050 . Especially India, China and Africa show a sharp increase of the share of transport in energy demand from $12 \%$ to $15 \%$ in 2005 to $26-30 \%$ in 2050 (IEA/SMP 2004). International marine shipping is not included in this study, due to a lack of regional data. Energy use from international marine shipping amounts to $9 \%$ of worldwide transport energy demand in 2005 and $7 \%$ in 2050 (IEA/SMP 2004).

Figure 4 gives the breakdown of final energy demand in the reference scenario for transport by mode in 2005 and 2050. The largest share of global energy use in transport is consumed by light duty vehicles (LDV; 48\%), followed by trucks $(26 \%)$. In 2050 , the share of LDV decreases to $44 \%$ of final energy demand in transport because of an expected growth in air transport, corresponding to $13 \%$ in 2005 and $19 \%$ in 2050 (IEA/SMP 2004). The shares for the other modes remain fairly the same.

For passenger transport (cars, air, rail, 2- and 3 -wheel and buses), the potentials for energy efficiency
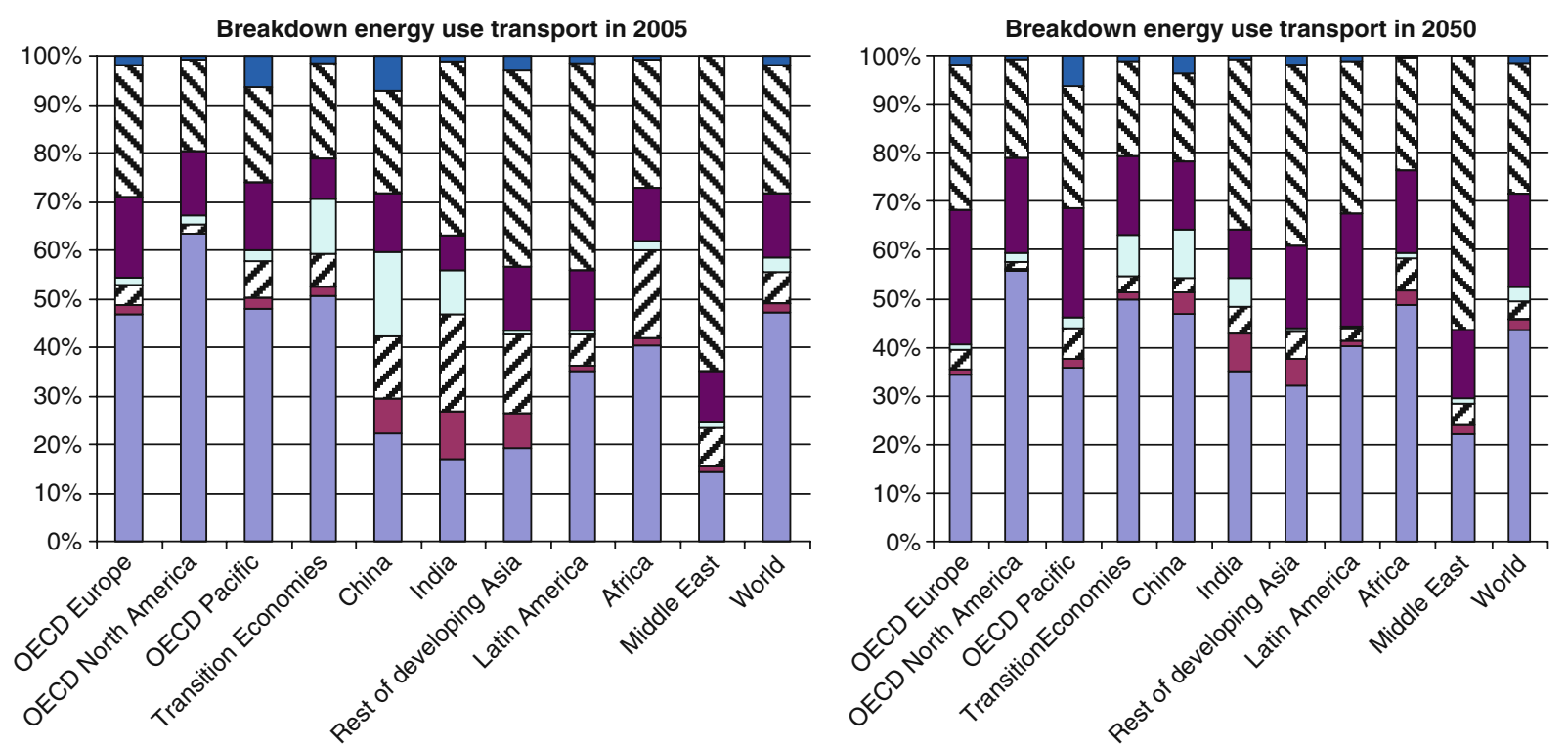

\begin{tabular}{|lllllll}
\hline$\square$ National marine $\quad \square$ Freight road $\quad \square$ Air $\quad \square$ Rail $\quad \square$ Buses $\quad \square$ 2/3-wheel $\quad \square$ LDV \\
\hline
\end{tabular}

Fig. 4 World final energy use per mode 2005 (IEA/SMP 2004) 
improvement are based on data regarding specific energy use in MJ per passenger-km or MJ per vehicle-km. For freight transport (road, rail and national marine), the potentials are based on data regarding MJ per tonne-km.

Passenger transport Many technologies can be used to improve the fuel efficiency of passenger cars. Examples are energy efficiency improvements in engines, weight reduction and friction and drag reduction (see for instance Smokers et al. 2006). The impact of the various measures on fuel efficiency can be substantial. Hybrid vehicles, combining a conventional combustion engine with an electric engine, have relatively low fuel consumption. The most well-known today is the Toyota Prius, which has a fuel efficiency of 4.01 gasoline equivalent ${ }^{1} / 100 \mathrm{~km}$ (1.3 MJ/v-km; Toyota 2010). Further developments are underway of new concept cars with specific fuel use as low as 3.01 gasoline equivalent $/ 100 \mathrm{~km}$ $(1.0 \mathrm{MJ} / \mathrm{v}-\mathrm{km})$. There are suggestions that applying new light materials, in combination with the new propulsion technologies, can bring fuel consumption levels down to 1.01 gasoline equivalent/100 km (Blok 2005). SRU (2005) gives a technical potential in 2050 for diesel cars of 1.61 gasoline equivalent $/ 100 \mathrm{~km}$ and for petrol cars 2.01 gasoline equivalent $/ 100 \mathrm{~km}$ in Europe. We assume that fuel consumption of average cars in OECD Europe can be as low as 2.01 gasoline equivalent/100 km in 2050 and we adapt the same improvement percentage in efficiency (about 3.2\% per year) for other regions.

Savings for air transport are based on Akerman (2005). He reports that $65 \%$ lower fuel intensity is technically feasible by 2050 . This is applied to 2005 energy intensity $(2.6 \mathrm{MJ} / \mathrm{p}-\mathrm{km})$ and results in $0.6 \mathrm{MJ} / \mathrm{p}-\mathrm{km}$ by 2050 .

The company Enova Systems estimates possible energy savings for buses of $50 \%$ on average. For minibuses, the ACEEE reports (DeCicco et al. 2001) a $55 \%$ fuel economy improvement by 2015 . Because no studies are available that estimate energy efficiency of buses in 2050, we assume that for buses, including minibuses, an energy efficiency improvement potential of $55 \%$ in 2050 , in comparison to the energy intensity level in 2005.

\footnotetext{
${ }^{1}$ One litre of gasoline equivalent is to $32 \mathrm{MJ}$ (lower heating value).
}

For two and three wheelers, the potential is based on IEA/SMP (2004), where 0.3 and $0.5 \mathrm{MJ} / \mathrm{p}-\mathrm{km}$ are the lowest values, respectively. The uncertainty in these potentials is high. However, two and three wheelers account only for $2 \%$ of transport energy demand.

Freight transport Elliott et al. (2006) give possible savings for heavy- and medium-duty freight trucks. The list of reduction options is expanded by Lensink and De Wilde (2007). For medium-duty trucks, a fuel economy saving of $50 \%$ is reported by 2030 (mainly due to hybridization); for heavy-duty trucks, savings are estimated at $39 \%$ by 2030 . We applied these percentages to 2005 energy intensity data, calculated the fuel economy improvement per year and extrapolated this improvement rate until 2050. For heavy-duty trucks, this corresponds to $1.0 \mathrm{MJ} / \mathrm{t}-\mathrm{km}$ in 2030 and $0.54 \mathrm{MJ} / \mathrm{t}-\mathrm{km}$ in 2050. Schäfer and Jacoby (2006) estimates that for trucks, $0.94 \mathrm{MJ} / \mathrm{t}-\mathrm{km}$ is possible by a reduction of rolling resistance, improved diesel engines and improved aerodynamics. Van Laar (1993) estimates that the energy requirement of heavy-duty freight trucks can be as low as $0.5 \mathrm{MJ} / \mathrm{t}-\mathrm{km}$.

Savings for passenger and freight rail were taken from Fulton and Eads (2004). They report a historic improvement in fuel economy of passenger rail of $1 \%$ per year and freight rail between 2\% and 3\% per year. Since no other sources are available for this study, we assume for the technical potential scenario $1 \%$ improvement of energy efficiency per year for passenger rail and $2 \%$ for freight rail.

National marine savings were taken from Lensink and De Wilde (2007). They report 20\% savings in 2030 for inland navigation as a realistic potential. To get to the potential in 2050, we applied these percentages to 2005 energy intensity data, calculated the fuel economy improvement per year and extrapolated the yearly improvement rate to 2050 .

Summary Table 3 shows specific energy consumption by region and transport mode in the reference scenario and in the technical potential scenario.

Table 4 shows energy efficiency improvement for transport by region, based on the decrease in specific energy consumption in 2050 in comparison to 2005 (Table 3) and on the breakdown of transport in p-km and $\mathrm{t}-\mathrm{km}$ by mode in 2050 (see Tables 14 and 15 in the Appendix). 
Table 3 Specific energy consumption by transport mode and region in reference scenario and technical potential scenario (values for reference scenario 2005 and 2050 from IEA/SMP 2004)

\begin{tabular}{|c|c|c|c|c|c|c|}
\hline & \multicolumn{3}{|c|}{ Freight (MJ/t-km) } & \multicolumn{3}{|c|}{ Passenger (MJ/p-km) } \\
\hline & 2005 & Reference 2050 & Technical potential 2050 & 2005 & Reference 2050 & Technical potential 2050 \\
\hline & \multicolumn{3}{|c|}{ Medium freight } & \multicolumn{3}{|l|}{ Buses } \\
\hline OECD Europe & 5.0 & 3.8 & 1.4 & 0.7 & 0.8 & 0.4 \\
\hline OECD North America & 4.2 & 3.2 & 1.2 & 1.0 & 1.0 & 0.5 \\
\hline OECD Pacific & 5.8 & 4.4 & 1.7 & 0.6 & 0.7 & 0.3 \\
\hline Transition economies & 5.9 & 4.0 & 1.7 & 0.5 & 0.6 & 0.3 \\
\hline China & 6.1 & 4.1 & 1.7 & 0.4 & 0.5 & 0.2 \\
\hline India & 6.2 & 4.2 & 1.8 & 0.4 & 0.5 & 0.2 \\
\hline Rest of developing Asia & 5.5 & 3.7 & 1.6 & 0.4 & 0.5 & 0.2 \\
\hline Latin America & 5.4 & 3.7 & 1.6 & 0.5 & 0.6 & 0.3 \\
\hline Africa & 7.1 & 4.8 & 2.0 & 0.4 & 0.5 & 0.2 \\
\hline Middle East & 6.3 & 4.3 & 1.8 & 0.5 & 0.6 & 0.3 \\
\hline \multirow[t]{2}{*}{ World Average } & 5.4 & 3.9 & 1.5 & 0.5 & 0.6 & 0.2 \\
\hline & \multicolumn{3}{|c|}{ Heavy freight } & \multicolumn{3}{|c|}{ Two-wheel } \\
\hline OECD Europe & 1.6 & 1.2 & 0.5 & 1.2 & 0.9 & 0.3 \\
\hline OECD North America & 1.5 & 1.2 & 0.5 & 1.4 & 1.0 & 0.3 \\
\hline OECD Pacific & 1.7 & 1.3 & 0.5 & 1.0 & 0.9 & 0.3 \\
\hline Transition economies & 1.9 & 1.3 & 0.5 & 0.7 & 0.8 & 0.3 \\
\hline China & 2.0 & 1.3 & 0.6 & 0.4 & 0.6 & 0.3 \\
\hline India & 2.0 & 1.4 & 0.6 & 0.4 & 0.6 & 0.3 \\
\hline Rest of developing Asia & 1.9 & 1.3 & 0.5 & 0.4 & 0.6 & 0.3 \\
\hline Latin America & 1.9 & 1.3 & 0.5 & 0.6 & 0.8 & 0.3 \\
\hline Africa & 2.0 & 1.4 & 0.6 & 0.4 & 0.6 & 0.3 \\
\hline Middle East & 2.0 & 1.3 & 0.6 & 0.6 & 0.8 & 0.3 \\
\hline \multirow[t]{2}{*}{ World Average } & 1.7 & 1.3 & 0.5 & 0.5 & 0.6 & 0.3 \\
\hline & \multicolumn{3}{|c|}{ Freight rail } & \multicolumn{3}{|c|}{ Three-wheel } \\
\hline OECD Europe & 0.4 & 0.4 & 0.1 & 0.9 & 0.9 & 0.5 \\
\hline OECD North America & 0.2 & 0.2 & 0.1 & 0.9 & 0.9 & 0.5 \\
\hline OECD Pacific & 0.4 & 0.4 & 0.1 & 0.9 & 0.9 & 0.5 \\
\hline Transition economies & 0.2 & 0.2 & 0.1 & 0.8 & 0.8 & 0.5 \\
\hline China & 0.3 & 0.3 & 0.1 & 0.7 & 0.7 & 0.5 \\
\hline India & 0.2 & 0.2 & 0.1 & 0.7 & 0.7 & 0.5 \\
\hline Rest of developing Asia & 0.2 & 0.2 & 0.1 & 0.7 & 0.7 & 0.5 \\
\hline Latin America & 0.2 & 0.2 & 0.1 & 0.7 & 0.7 & 0.5 \\
\hline Africa & 0.2 & 0.2 & 0.1 & 0.7 & 0.7 & 0.5 \\
\hline Middle East & 0.2 & 0.2 & 0.1 & 0.7 & 0.7 & 0.5 \\
\hline \multirow[t]{2}{*}{ World Average } & 0.2 & 0.2 & 0.1 & 0.7 & 0.7 & 0.5 \\
\hline & \multicolumn{3}{|c|}{ National marine } & \multicolumn{3}{|c|}{ LDV (litre/100 v-km) } \\
\hline OECD Europe & 1.2 & 0.8 & 0.6 & 7.8 & 5.9 & 2.0 \\
\hline OECD North America & 0.7 & 0.5 & 0.4 & 11.5 & 10.0 & 3.0 \\
\hline OECD Pacific & 0.3 & 0.2 & 0.2 & 10.2 & 7.5 & 2.6 \\
\hline Transition economies & 1.2 & 0.8 & 0.6 & 10.0 & 8.5 & 2.6 \\
\hline China & 1.2 & 0.8 & 0.6 & 11.5 & 8.5 & 2.9 \\
\hline
\end{tabular}


Table 3 (continued)

\begin{tabular}{|c|c|c|c|c|c|c|}
\hline & \multicolumn{3}{|c|}{ Freight (MJ/t-km) } & \multicolumn{3}{|c|}{ Passenger (MJ/p-km) } \\
\hline & 2005 & Reference 2050 & Technical potential 2050 & 2005 & Reference 2050 & Technical potential 2050 \\
\hline India & 1.2 & 0.8 & 0.6 & 11.0 & 8.2 & 2.8 \\
\hline Rest of developing Asia & 1.2 & 0.8 & 0.6 & 11.5 & 8.4 & 2.9 \\
\hline Latin America & 1.2 & 0.8 & 0.6 & 11.4 & 8.3 & 2.9 \\
\hline Africa & 1.2 & 0.8 & 0.6 & 13.5 & 9.3 & 3.5 \\
\hline Middle East & 1.2 & 0.8 & 0.6 & 11.6 & 8.3 & 3.0 \\
\hline World Average & 0.7 & 0.5 & 0.4 & 10.4 & 8.5 & 2.8 \\
\hline \multirow[t]{2}{*}{ All regions } & & & & \multicolumn{3}{|l|}{ Air } \\
\hline & & & & 2.6 & 1.9 & 0.9 \\
\hline \multirow[t]{2}{*}{ All regions } & & & & \multicolumn{3}{|c|}{ Passenger rail } \\
\hline & & & & 0.3 & 0.3 & 0.2 \\
\hline
\end{tabular}

Globally, the resulting technical potential for energy efficiency improvement in transport amounts to $2.8 \%$ per year. As the energy efficiency improvement already occurring in the reference scenario is $0.5 \%$ per year (IEA/SMP 2004), a potential of $2.3 \%$ per year exists in comparison to the reference scenario.

Figure 5 shows the development of transport energy demand in the reference scenario and the resulting energy demand in the technical potential scenario, based on the energy efficiency improvement in Table 4.

\section{Industry}

The worldwide average share of industry in total final energy demand is about $30 \%$. The share in Africa is lowest with $16 \%$ in 2050. The share in China is highest with $43 \%$ in 2050 . For the industry sector, technical potentials for energy efficiency improvement are based on (1) implementing best practice and emerging technologies and (2) increased material efficiency (including recycling).

IEA (2008a, b, c) estimates an average potential of $19-32 \%$ by implementing best available techniques

Table 4 Energy efficiency improvement transport in period 2010-2050 (\%/year) ${ }^{\mathrm{a}}$

\begin{tabular}{lccc}
\hline Region & $\begin{array}{l}\text { Energy efficiency } \\
\text { improvement } \\
\text { potential (\%/year) }\end{array}$ & $\begin{array}{l}\text { Autonomous energy efficiency } \\
\text { improvement in reference } \\
\text { scenario (\%/year) }\end{array}$ & $\begin{array}{l}\text { Energy efficiency improvement } \\
\text { in comparison to reference } \\
\text { scenario (\%/year) }\end{array}$ \\
\hline World & $2.8 \%$ & $0.5 \%$ & $2.3 \%$ \\
OECD North America & $3.0 \%$ & $0.4 \%$ & $2.6 \%$ \\
OECD Europe & $2.9 \%$ & $0.6 \%$ & $2.3 \%$ \\
OECD Pacific & $2.8 \%$ & $0.6 \%$ & $2.2 \%$ \\
Transition economies & $2.8 \%$ & $0.4 \%$ & $2.4 \%$ \\
India & $2.4 \%$ & $0.3 \%$ & $2.1 \%$ \\
China & $2.4 \%$ & $0.4 \%$ & $2.0 \%$ \\
Rest of developing Asia & $2.6 \%$ & $0.5 \%$ & $2.1 \%$ \\
Latin America & $2.9 \%$ & $0.5 \%$ & $2.4 \%$ \\
Middle East & $2.9 \%$ & $0.7 \%$ & $2.2 \%$ \\
Africa & $2.8 \%$ & $0.7 \%$ & $2.1 \%$
\end{tabular}

${ }^{\mathrm{a}}$ Energy efficiency improvement here refers to a decrease in specific energy consumption (in $\mathrm{MJ} / \mathrm{p}-\mathrm{km}$ for passenger transport and $\mathrm{MJ} /$ $\mathrm{t}-\mathrm{km}$ for freight transport) 
Fig. 5 Energy demand in transport in reference scenario and technical potential scenario $(\mathrm{EJ})$
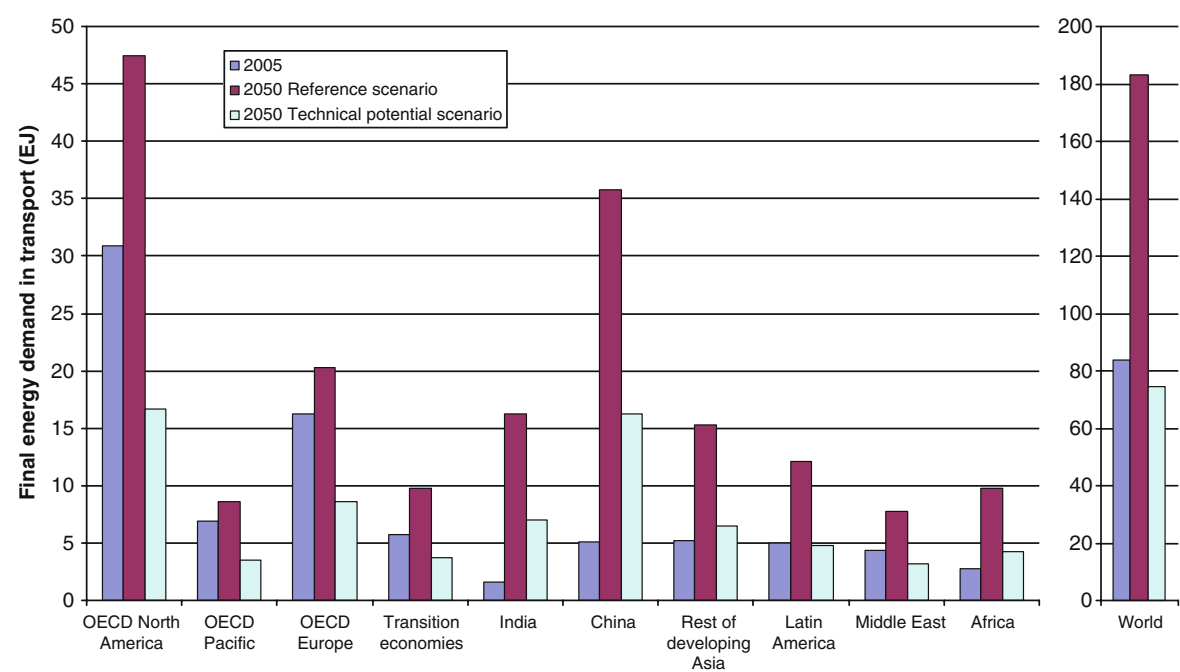

(BAT) globally and an additional potential of $20-30 \%$ for new technologies. Together, this amounts to a potential of $35-52 \%$ for implementing BAT and emerging technologies, varying per sector. We use an average of $45 \%$ in our calculations. In order to illustrate the potential of best practice and emerging technologies in industry, we give a couple of examples for a few energy-intensive industrial processes: cement production, ammonia production, chlorine production and aluminium production.

- Cement production: Two important processes in producing cement are clinker production and the blending of clinker with additives to produce cement. Clinker production is the most energyintensive step in cement production. The current state of the art kilns consume $3.0 \mathrm{GJ} /$ tonne clinker. The thermodynamic minimum is $1.8 \mathrm{GJ} /$ tonne clinker, but strongly depends on the moisture content of the raw materials and fuels. The global average specific energy consumption per tonne clinker equals 4.2 GJ per tonne (based on REEEP 2008). Based on current state of the art this implies a savings potential of $30 \%$.

- Ammonia production: Ammonia production consumed more energy than any other process in the chemical industry and accounted for $18 \%$ of the energy consumed in this sector. Ammonia is mainly applied as a feedstock for fertilizer production. Current best practice energy intensity (excluding feedstock) $^{2}$ is $8 \mathrm{GJ} /$ tonne ammonia (Sinton et al. 2002). Average energy use for ammonia production in 2005 is equivalent to $15 \mathrm{GJ} /$ tonne $^{3} \mathrm{NH}_{3}$ (REEEP 2008). This corresponds to an average savings potential of $45 \%$ based on current best practice technology.

- Chlorine production: Chlorine production is the main electricity consuming process in the chemical industry, followed by oxygen and nitrogen production. The most efficient production process for chlorine production is the membrane process that consumes 2,600 kWh/tonne chlorine, which is already close to the most efficient technology considered feasible (IEA 2008a, b, c and Sinton et al. 2002). At the moment, however, the mercury process is still commonly used for chlorine production, with an energy intensity of around 4,000-4,500 kWh/tonne chlorine. Worldwide, the average energy intensity for chlorine production is around 3,600 kWh/tonne ${ }^{4}$ chlorine (IEA 2008a, b, c and Sinton et al. 2002). This corresponds to a savings potential of $28 \%$ for electricity use in chlorine production, based on the application of membrane technology.

\footnotetext{
${ }^{2}$ Around $20 \mathrm{GJ} /$ tonne $\mathrm{NH}_{3}$

${ }^{3} 15 \mathrm{GJ} /$ tonne $\mathrm{NH}_{3}$ for the European Union, $18 \mathrm{GJ} /$ tonne for the United States, $20 \mathrm{GJ} /$ tonne for Russia, $30 \mathrm{GJ} /$ tonne for China and $23 \mathrm{GJ} /$ tonne for India

${ }^{4} 3,000 \mathrm{kWh} /$ tonne in Japan, 3,500 $\mathrm{kWh} /$ tonne in Western Europe and 4,300 kWh/tonne in the United States
} 
- Aluminium production: The worldwide energy intensity for aluminium production is $15.3 \mathrm{MWh}$ per tonne of aluminium in 2006 (based on USGS 2008 and International Aluminium Institute 2008). The theoretical minimum energy requirement for electrolysis is $6.4 \mathrm{MWh} /$ tonne (IEA 2008a, b, c). The current best practice is $12-13 \mathrm{MWh}$ per tonne (Worrell et al. 2008), which implies an improvement potential of $20 \%$.

A second means of reducing energy use in industries is material efficiency, by which is meant a reduction of the amount of primary material needed to fulfil a specific function. This can be achieved by, e.g. re-designing a product to a lower material intensity by reducing the amount of material needed to manufacture a unit of a product or material recycling, where secondary material is produced by recycling of material (Worrell et al. 1995).

In order to estimate the potential for material efficiency, we look into a couple of examples:

- Iron and steel recycling: The energy efficiency for iron and steel production is influenced by the technologies used and the amount of scrap input. The energy intensity for recycled steel is around $70-75 \%$ lower than the energy intensity for primary steel. The most energy-intensive part of steel making is the reduction of iron oxide. The higher the share of iron in total steel production (i.e. the lower the share of scrap input used) the higher the specific energy consumption. In 2005, $35 \%$ of all crude steel production is derived from scrap (IEA 2006). The potential for recycling steel depends on the availability of scrap. Neelis and Patel (2006) estimate that the potential for the share of scrap in total steel production can be between $60 \%$ and $70 \%$ by 2100 . Based on $70 \%$ lower energy intensity for recycled steel and 50\% steel recycling in 2050 (average of $35 \%$ in 2005 and $65 \%$ in 2100 ), this results in $14 \%$ savings due to steel recycling in 2050.

- Aluminium recycling: The production of primary aluminium from alumina (made out of bauxite) is an energy-intensive process. Secondary aluminium, produced out of recycled scrap uses only $5 \%$ of the energy demand for primary production because it involves remelting of the metal instead of the electrochemical reduction process (Phylipsen,
2000). Around 16 million tonnes of aluminium was recycled in 2006 worldwide, which fulfilled around $33 \%$ of the global demand for aluminium (46 million tonnes; World Aluminium 2008). Of the total amount of recycled aluminium, approximately $17 \%$ comes from packaging, 38\% from transport, $32 \%$ from building and 13\% from other products. Recycling rates of aluminium can be further increased, e.g. in Sweden, 92\% of aluminium cans are recycled and in Switzerland $88 \%$, while the European average is only $40 \%$ (European Aluminium Association 2008). The recycling rates for building and transport applications also show a wide range from $60 \%$ to $90 \%$ in various countries. If the recycling rate of aluminium can be increased from $33 \%$ to $50 \%$ of aluminium production in 2050 , this would lead to energy savings of $22 \%$ in 2050.

- Cement production-reduce clinker content: The energy use per tonne cement ranges from 1.2 to $5 \mathrm{GJ} /$ tonne cement and depends largely on the share of clinker in cement production (ENCI 2002). Substantial energy savings can be obtained by reducing the amount of clinker required. One option to reduce clinker use is by substituting clinker by industrial by-products such as coal fly ash, blast furnace slag or pozzolanic materials (e.g. volcanic material). The relative importance of additive use can be expressed by the clinker to cement ratio. The clinker to cement ratio for current cement production ranges from $25 \%$ to $99 \%$ and the average clinker to cement ratio equals $80 \%$ (ENCI 2002). If this ratio would be reduced to $50 \%$, this corresponds to an energy savings potential of $35 \%$, assuming sufficient substitution material is available.

- Material efficiency of plastics production: Worrell et al. (1995) estimate a technical potential for material efficiency in (virgin) plastics production of $31 \%$, of which $45 \%$ can be achieved by efficient product design, $35 \%$ by recycling, $12 \%$ by good housekeeping and $8 \%$ by material substitution. Hekkert et al. (1998) indicate that it is possible to reduce $\mathrm{CO}_{2}$ emissions related to packaging in Europe by more than $50 \%$ in the period 2000-2020 by lighter packaging, reusable packaging, material substitution and the use of recycled material. 
The examples above identify three important ways of improving material efficiency: (1) increased recycling (iron and steel, aluminium and plastics show a potential of $14 \%, 22 \%$ and $11 \%$, respectively), (2) efficient product design (this could increase energy efficiency of plastics production by $15 \%$ ) and (3) material substitution (e.g. replacing clinker in cement could reduce energy use by $35 \%$ and $2 \%$ for plastics production). The potential per industrial subsector differs. For the total potential for material efficiency in industry in 2050, we assume $30 \%$ of which efficient design is estimated to have a technical potential of $\sim 15 \%$, recycling of $\sim 10 \%$ and other measures of $\sim 5 \%$ (e.g. material substitution).

Together with the implementation of best practice technologies and emerging technologies, this leads to a savings potential of $62 \%$ in 2050 , which corresponds to $2.4 \%$ per year in the period 2010-2050. Since we assume that $1 \%$ energy efficiency improvement occurs in the baseline, based on historical development of energy efficiency improvement (Blok (2005) and Odyssee (2005)), this means that $\sim 1.4 \%$ per year energy efficiency improvement can be achieved additional to the baseline.

Summary For all regions, the same savings potential is assumed for industry of $1.4 \%$ per year in comparison to the reference scenario. Figure 6 shows the resulting energy demand in the technical potential scenario and in the reference scenario by world region.

\section{Buildings and others}

Energy consumed in buildings (including agriculture) represents approximately $40 \%$ of global final energy consumption. The share of residential buildings is largest and accounts for $50-80 \%$ of energy demand in buildings (depending on region), followed by commercial buildings (10-50\%) and agriculture (1-10\%). The potential for energy efficiency improvement is calculated per type of energy use: fuel and heat use (space heating, cooking, hot water use) and electricity consumption (lighting, standby power, cold appliances, other appliances and air conditioning).

Fuel and heat use Fuel and heat use account for 75\% of final energy demand in buildings (and 52\% in primary energy demand). Fuel and heat is mainly used for hot water production, cooking and for space heating. Space heating accounts for the largest share of fuel and heat use, around $80 \%$ globally, followed by hot water production (15\%) and cooking (5\%; Bertoldi and Atanasiu 2006, IEA 2006 and WBCSD 2005).

An indicator for the energy efficiency of space heating is the energy demand per square metre floor area per heating degree day (HDD). Heating degree days is the number of degrees that a day's average temperature is below $18^{\circ} \mathrm{C}$, the temperature below which buildings are usually heated. Typical current heating demand for dwellings is $50-110 \mathrm{~kJ} / \mathrm{m}^{2} / \mathrm{HDD}$ (based on IEA 2007c), while dwellings with a low-
Fig. 6 Energy demand in industry in reference scenario and technical potential scenario (EJ)
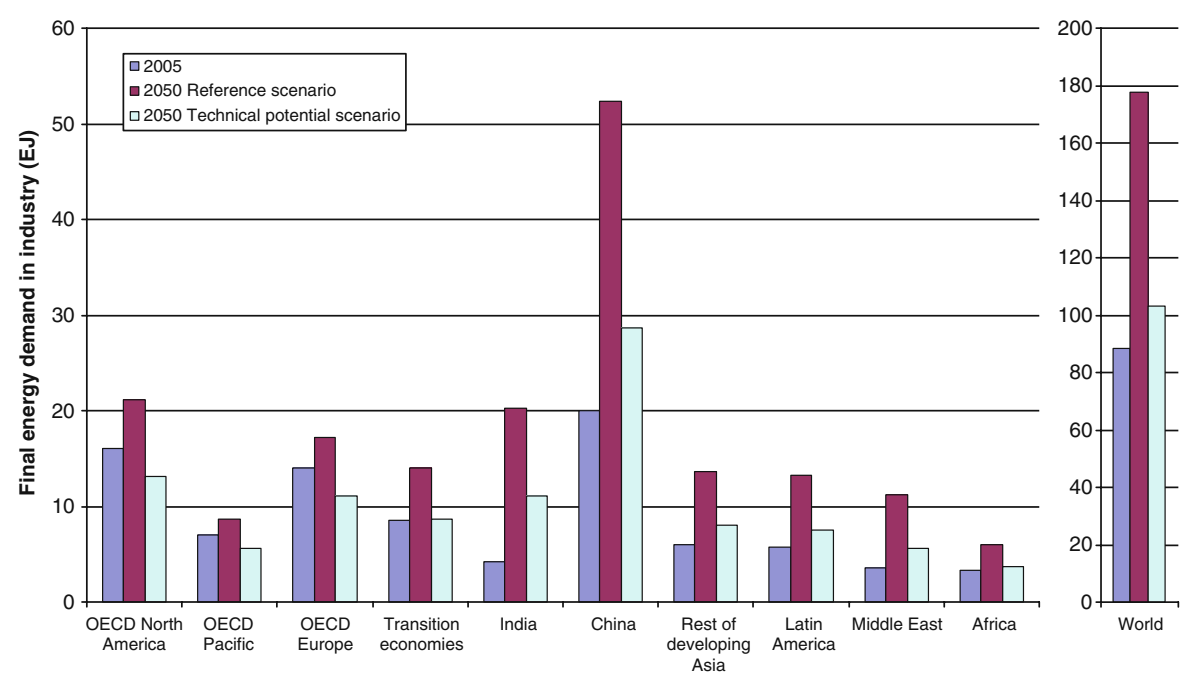
energy use consume below $32 \mathrm{~kJ} / \mathrm{m}^{2} / \mathrm{HDD}$. $^{5}$ Technologies to limit energy demand of new dwellings are (WBCSD 2005; IEA 2006; Joosen et al. 2002):

$>$ Triple-glazed windows with low-emittance coatings, which reduce heat loss to $40 \%$ compared to windows with one layer. The low-emittance coating prevents energy waves in sunlight coming in and thereby reduces cooling need.

$\triangleright$ Insulation of roofs, walls, floors and basement. Proper insulation reduces heating and cooling demand by $50 \%$ in comparison to average energy demand.

$\triangleright$ Passive solar energy, which makes use of the supply of solar energy by means of building design (building's site and window orientation). The term 'passive' indicates that no mechanical equipment is used. All solar gains are brought in through windows.

$>$ Balanced ventilation with heat recovery. Heated indoor air passes to a heat recovery unit and is used to heat incoming outdoor air.

Current specific space heating demands in dwellings in OECD countries are given in Table 5. An explanation for the difference could be a difference in comfort level. For the technical potentials, we assume that no change in the comfort level in comparison to the reference scenario occurs.

For the technical potential, it is assumed that starting in 2010, all new dwellings can be lowenergy dwellings using $32 \mathrm{~kJ} / \mathrm{m}^{2} / \mathrm{HDD}$ for OECD regions. For transition economies, we assume the average of OECD savings potential. For non-OECD countries, no data is available. Therefore, the potentials for space heating in non-OECD countries are based on Ürge-Vorsatz and Novikova (2008). They estimate a total energy efficiency improvement potential of $1.4 \%$ per year for the period 2005-2030 for developing regions for both new dwellings and for improving energy efficiency in existing houses ('retrofitting'). Here, we assume that this improvement rate can be achieved for the period 2010-2050.

\footnotetext{
5 This is based on a number of zero-energy dwelling in The Netherlands and Germany, consuming $400-500 \mathrm{~m}^{3}$ natural gas per year, with a floor surface between 120 and $150 \mathrm{~m}^{2}$. This results in $0.1 \mathrm{GJ} / \mathrm{m}^{2} /$ year and is converted by 3,100 heating degree days to $32 \mathrm{~kJ} / \mathrm{m}^{2} / \mathrm{HDD}$.
}

Table 5 Space heating demands in OECD dwellings in 2004 (IEA 2007c)

\begin{tabular}{ll}
\hline Region & $\begin{array}{l}\text { Specific space heating } \\
\left(\mathrm{kJ} / \mathrm{m}^{2} / \mathrm{HDD}\right)\end{array}$ \\
\hline OECD Europe & 113 \\
OECD North America & 78 \\
OECD Pacific & 52 \\
\hline
\end{tabular}

For existing houses in OECD countries, the potential for efficiency improvement by retrofitting is based on IEA (2006). Important retrofit options are more efficient windows and insulation. According to IEA (2006), the former can save $39 \%$ of space heating energy demand of current buildings, while the latter can save $32 \%$ of space heating or cooling energy demand. IEA (2006) reports that average energy consumption in current buildings in Europe can decrease by more than $50 \%$. Here, $50 \%$ is used as the technical potential for OECD Europe in 2050. For the other OECD regions, the same relative reduction in comparison to OECD Europe is assumed as for new buildings, to take into account current average efficiency of dwellings in the regions. This means that potential savings in existing buildings in OECD North America amount to $41 \%$ and in OECD Pacific to $27 \%$.

To calculate overall potentials for space heating demand in dwellings in OECD countries and transition economies, the share of buildings built after 2010 in total dwelling stock in 2050 is estimated. The UNECE database (UNECE 2008) contains data on total dwelling stock, dwelling stock increase (new construction) and population. It is assumed that the total dwelling stock grows along with population. The number of existing dwellings decreases every year due to a certain replacement. On average, this is about $1.3 \%$ of total dwelling stock per year, meaning $40 \%$ replacement in 40 years (this is equivalent to an average house lifetime of 100 years). Table 6 gives the share of new dwellings in the total dwelling stock per region. The low growth rate for new dwellings in OECD Pacific is due to a decrease of population by $11 \%$ from 200 million in 2005 to 178 million in 2050 . OECD North America on the other hand has a population growth of $32 \%$ from 436 million in 2005 to 577 million in 2050 . 
Table 6 Forecasted share of new dwellings (of share of dwelling stock) in 2050

\begin{tabular}{|c|c|c|c|}
\hline Region & Existing buildings & $\begin{array}{l}\text { New dwellings due to replacement } \\
\text { of old buildings as share of total } \\
\text { dwellings in } 2050\end{array}$ & $\begin{array}{l}\text { New dwellings due to } \\
\text { population growth as share } \\
\text { of total in } 2050\end{array}$ \\
\hline OECD Europe & $52 \%$ & $41 \%$ & $7 \%$ \\
\hline OECD North America & $36 \%$ & $29 \%$ & $35 \%$ \\
\hline OECD Pacific & $55 \%$ & $44 \%$ & $1 \%$ \\
\hline Transition economies & $55 \%$ & $45 \%$ & $0 \%$ \\
\hline
\end{tabular}

Total savings for space heating energy demand are calculated by multiplying the savings potentials for new and existing houses with the forecasted share of dwellings in 2050 to get a weighted reduction percentage (see Table 7).

For space heating in buildings in the services sector, the same percentual savings as for dwellings are assumed. Also for fuel use for hot water and cooking, we assume the same percentual reduction as is assumed for space heating per region. This is done because no sources are available that give potentials for these two types of energy use. Note that the share of these two is small in comparison to space heating. Measures for reducing fuel use for hot water consumption are, e.g. the use of heat recovery units to use heat from waste water, the use of efficient boilers and limitation of excess water flow. Hot water that goes down the drain carries energy with it. Heat recovery systems can capture energy to preheat cold water entering the water heater. A heat recovery system can recover as much as $70 \%$ of this heat and recycle it back for immediate use (Enviroharvest 2008).

Electricity use The breakdown of electricity use per type of appliance is different per region. In this scenario, a convergence is assumed for the different types of electricity demand per region in 2050. Based on Bertoldi and Atanasiu (2006), IEA (2006), and WBCSD (2005), the following breakdown for electricity use in 2050 is assumed for all regions:

- Standby $(8 \%)$

- Lighting (15\%)

- Cold appliances (15\%)

- Appliances (30\%)

- Air conditioning (8\%)

- Other (e.g. electric heating; 24\%)

Standby power consumption Standby power consumption is the 'lowest power consumption which cannot be switched off (influenced) by the user and may persist for an indefinite time when an appliance is connected to the main electricity supply' (UK MTP 2008). Standby power accounts for 20-90 $\mathrm{W}$ per home in developed nations, ranging from $4 \%$ to $10 \%$ of residential electricity use (Meier et al., 2004). Globally, standby power consumption in residential electricity use is estimated to range from $3 \%$ to $12 \%$ (Meier, 2001). Efficiency recommendations of the US FEMP and Energy Star Label (US FEMP

Table 7 Specific space heating demand $\left(\mathrm{kJ} / \mathrm{m}^{2} / \mathrm{HDD}\right)$ in dwellings (\% share in total dwellings in 2050)

\begin{tabular}{|c|c|c|c|c|c|}
\hline & $\begin{array}{l}\text { Average dwellings } \\
\text { in } 2004\end{array}$ & $\begin{array}{l}\text { New dwellings } \\
(>2010)\end{array}$ & $\begin{array}{l}\text { Retrofitted dwellings } \\
\text { in } 2050\end{array}$ & $\begin{array}{l}\text { Average dwelling } \\
\text { in } 2050\end{array}$ & $\begin{array}{l}\text { Energy efficiency } \\
\text { improvement in } 2050 \text { in } \\
\text { comparison to } 2004\end{array}$ \\
\hline OECD Europe & 113 & $35(48 \%)$ & $57(52 \%)$ & 46 & $59 \%$ \\
\hline OECD North America & 78 & $35(64 \%)$ & $47(36 \%)$ & 39 & $50 \%$ \\
\hline OECD Pacific & 52 & $35(45 \%)$ & $38(55 \%)$ & 37 & $29 \%$ \\
\hline Transition economies & $\begin{array}{l}81 \text { (assumption, } \\
\text { average OECD) }\end{array}$ & $35(45 \%)$ & $49(55 \%)$ & 43 & $47 \%$ \\
\hline Other non-OECD countries & NA & NA & NA & NA & $46 \%$ \\
\hline
\end{tabular}


2007) assume best practice levels for all equipment of $1 \mathrm{~W}$ or less. A study by Harmelink et al. (2005) reported significant savings (up to 77\%) if a standby standard of $1 \mathrm{~W}$ per appliances would be enforced. WBCSD (2005) reports a worldwide savings potential between $72 \%$ and $82 \%$. For the technical potential, a savings potential of $82 \%$ in 2050 is assumed.

Lighting An indicator for the efficiency of lighting is the luminous efficacy $(\mathrm{lm} / \mathrm{W})$ of average lamps used in a region. The luminous efficacy is a ratio of the visible light energy emitted (the luminous flux) to the total power input to the lamp. It is measured in lumens per watt $(\mathrm{lm} / \mathrm{W})$. The maximum efficacy possible is $240 \mathrm{~lm} / \mathrm{W}$ for white light. The current best practice is $75 \mathrm{~lm} / \mathrm{W}$ for fluorescent lights (future fluorescent lights $100 \mathrm{~lm} / \mathrm{W}$ ) and $115 \mathrm{~lm} / \mathrm{W}$ for white LEDs (future LEDs $150 \mathrm{~lm} / \mathrm{W}$; LEDS Magazine 2007). The luminous efficacy of incandescent lamps is $10-17 \mathrm{~lm} / \mathrm{W}$. For the technical potential in 2050 , we assume that the average luminous efficacy can be increased to $100 \mathrm{~lm} / \mathrm{W}$ in all regions, taking into account that it might not be possible to use LEDs for all purposes.

Table 8 below shows the luminous efficacy per region and the technical potential in 2050. This is based on Bertoldi and Atanasiu (2006) and Waide (2007), where national lighting consumption and CFL penetration data is presented by region. This information is combined with the luminous efficacy per lamp type as given above.
Cold appliances Energy efficiency improvement for cold appliances is based on the situation in the EU. In 2003, 103 TWh was consumed by household cold appliances in the EU-15 countries (15\% of total 2004 residential end use). An average energy label $\mathrm{A}++$ cold appliance uses $120 \mathrm{kWh}$ per year, while a comparable appliance of energy label B uses on average $300 \mathrm{kWh}$ per year (and C label $600 \mathrm{kWh}$ per year; EuroTopten 2008a). The average energy label of appliances sold in EU-15 countries is still label B in 2008. If only $\mathrm{A}++$ appliances were sold, energy consumption would be $60 \%$ less. The average lifetime of a cold appliance is 15 years, meaning that 15 years from the introduction of only $\mathrm{A}++$ labelled appliances, $60 \%$ less energy would be used in EU-15 countries (EuroTopten 2008a).

European Commission (2005) estimates a savings potential for cold appliances of $3.5 \%$ per year for the period 2003-2010. We use this energy efficiency improvement rate for the period 2010-2050. This means that for EU-15 the average cold appliance would use $72 \mathrm{kWh}$ per year in 2050 .

Other appliances WBCSD (2005) estimates a savings potential for other electric appliances of $70 \%$ in 2050. We use this potential in the scenario (equivalent to $3.0 \%$ per year improvement in the period 2010-2050). Main energy consuming appliances are computers, servers and set-top boxes. For example: the average desktop computer uses about $120 \mathrm{~W}$ (the monitor $75 \mathrm{~W}$ and the central process-

Table 8 Average luminous efficacy of residential lamps

\begin{tabular}{llll}
\hline Region & $\begin{array}{l}\text { Luminous efficacy } \\
(\mathrm{lm} / \mathrm{W})\end{array}$ & $\begin{array}{l}\text { Technical potential for } \\
\text { energy efficiency } \\
\text { improvement in } 2050^{\mathrm{a}}\end{array}$ & $\begin{array}{l}\text { \% energy efficiency } \\
\text { improvement per year }\end{array}$ \\
\hline OECD Europe & 40 & $60 \%$ & $2.3 \%$ \\
OECD Pacific (based on Japan) & 65 & $35 \%$ & $1.1 \%$ \\
OECD North America & 30 & $70 \%$ & $3.0 \%$ \\
Transition economies (TE) & 20 & $80 \%$ & $3.9 \%$ \\
China & 50 & $50 \%$ & $1.7 \%$ \\
Other regions (India, Rest of developing & $20^{\mathrm{b}}$ & $80 \%$ & $3.9 \%$ \\
$\quad$ Asia, Latin America, Africa, Middle East) & 40 & $60 \%$ & $2.4 \%$ \\
\hline
\end{tabular}

\footnotetext{
${ }^{\mathrm{a}}$ The technical potential refers to the degree to which the luminous efficacy in $1 \mathrm{~m} / \mathrm{W}$ can be improved if the average luminous efficacy is improved to $100 \mathrm{~lm} / \mathrm{W}$

${ }^{\mathrm{b}}$ For other developing regions no information is available. We assume the same luminous efficacy as for transition economies
} 
ing unit $45 \mathrm{~W})$. Best practice monitors in 2008 (EuroTopten 2008b) used only $18 \mathrm{~W}$ (15 in.), which is $76 \%$ less than average. In 2010, TFT-LED monitors are available that use $12.5 \mathrm{~W}$ (18 in; Philips 2010).

Air conditioning For air conditioning, we assume a savings potential of $70 \%$ in 2050 , based on WBCSD (2005). The potential takes into account that a share of conventional air conditioners is replaced by solar cooling and geothermal cooling and that the remaining units use refrigerant Ikon $\mathrm{B}$. Tests with the refrigerant Ikon B show possible energy consumption reductions of $20-25 \%$ compared to regularly used refrigerants (US DOE EERE 2008). Solar cooling is the use of solar thermal energy or solar electricity to power a cooling appliance. To drive the pumps, only $0.05 \mathrm{~kW}$ of electricity is needed (instead of $0.35 \mathrm{~kW}$ for regular air conditioning; Austrian Energy Agency 2006); this results in a savings potential of $85 \%$. Besides efficient air conditioning equipment, it is as important to reduce the need for air conditioning. Important ways to reduce cooling demand are: insulation to prevent heat from entering the building, reduce the amount of inefficient appliances present in the house (such as incandescent lamps, old refrigerators, etc.) that give off unusable heat, use cool exterior finishes (such as cool roof technology (US EPA 2007) or light-coloured paint on the walls) to reduce the peak cooling demand (as much as $10-15 \%$ according to ACEEE (2007)), improve windows and use vegetation to reduce the amount of heat that comes into the house and use ventilation instead of air conditioning units.

Summary Table 9 shows energy efficiency improvement for buildings by region. The potential for electricity demand reduction is estimated to be $3 \%$ per year and thereby, higher than the potential for fuel and heat demand, which is $1.5-2 \%$ per year. The reason for this can be found in the longer life time of buildings (typically more than 50 years), in comparison to the lifetime for electric appliances (typically $5-15$ years).

The overall technical potential for energy demand reduction in buildings is estimated to be $2.2 \%$ per year, globally. Since we assume that $1 \%$ energy efficiency improvement occurs in the baseline, based on historical development of energy efficiency improvement (Blok (2005) and Odyssee (2005)), this means that $\sim 1.1 \%$ per year energy efficiency improvement can be achieved in addition to the baseline. Figure 7 shows the resulting development of energy demand in buildings in the technical potential scenario.

Table 9 Technical energy efficiency potential for different types of energy uses within the buildings sector (\% per year period 2010-2050)

\begin{tabular}{|c|c|c|c|c|c|c|c|c|}
\hline & \multirow{2}{*}{$\begin{array}{l}\begin{array}{l}\text { Fuel and heat } \\
\text { consumption }\end{array} \\
\begin{array}{l}\text { Space heating } \\
\text { and others }\end{array}\end{array}$} & \multicolumn{6}{|c|}{ Electricity consumption (\%/year) } & \multirow{2}{*}{$\begin{array}{l}\text { Total potential } \\
\text { (\%/year) }\end{array}$} \\
\hline & & Standby & Lighting & Appliances & $\begin{array}{l}\text { Cold } \\
\text { appliances }\end{array}$ & $\begin{array}{l}\text { Air } \\
\text { conditioning }\end{array}$ & $\begin{array}{l}\text { Other/ } \\
\text { average }\end{array}$ & \\
\hline OECD Europe & $2.3 \%$ & $4.2 \%$ & $2.3 \%$ & $3.0 \%$ & $3.5 \%$ & $3 \%$ & $3.1 \%$ & $2.6 \%$ \\
\hline OECD North America & $1.8 \%$ & & $3.0 \%$ & & & & $3.2 \%$ & $2.5 \%$ \\
\hline OECD Pacific & $0.9 \%$ & & $1.0 \%$ & & & & $2.8 \%$ & $2.0 \%$ \\
\hline Transition economies & $1.6 \%$ & & $3.9 \%$ & & & & $3.4 \%$ & $2.0 \%$ \\
\hline China & $1.4 \%$ & & $1.7 \%$ & & & & $3.0 \%$ & $2.0 \%$ \\
\hline India & $1.4 \%$ & & $3.9 \%$ & & & & $3.4 \%$ & $2.2 \%$ \\
\hline Rest developing Asia & $1.4 \%$ & & & & & & & $2.0 \%$ \\
\hline Middle East & $1.4 \%$ & & & & & & & $2.2 \%$ \\
\hline Latin America & $1.4 \%$ & & & & & & & $2.2 \%$ \\
\hline Africa & $1.4 \%$ & & & & & & & $1.8 \%$ \\
\hline World & $1.7 \%$ & $4.2 \%$ & $2.4 \%$ & $3 \%$ & $3.5 \%$ & $3 \%$ & $3.1 \%$ & $2.2 \%$ \\
\hline
\end{tabular}


Fig. 7 Energy demand in buildings in reference scenario and technical potential scenario $(\mathrm{EJ})$

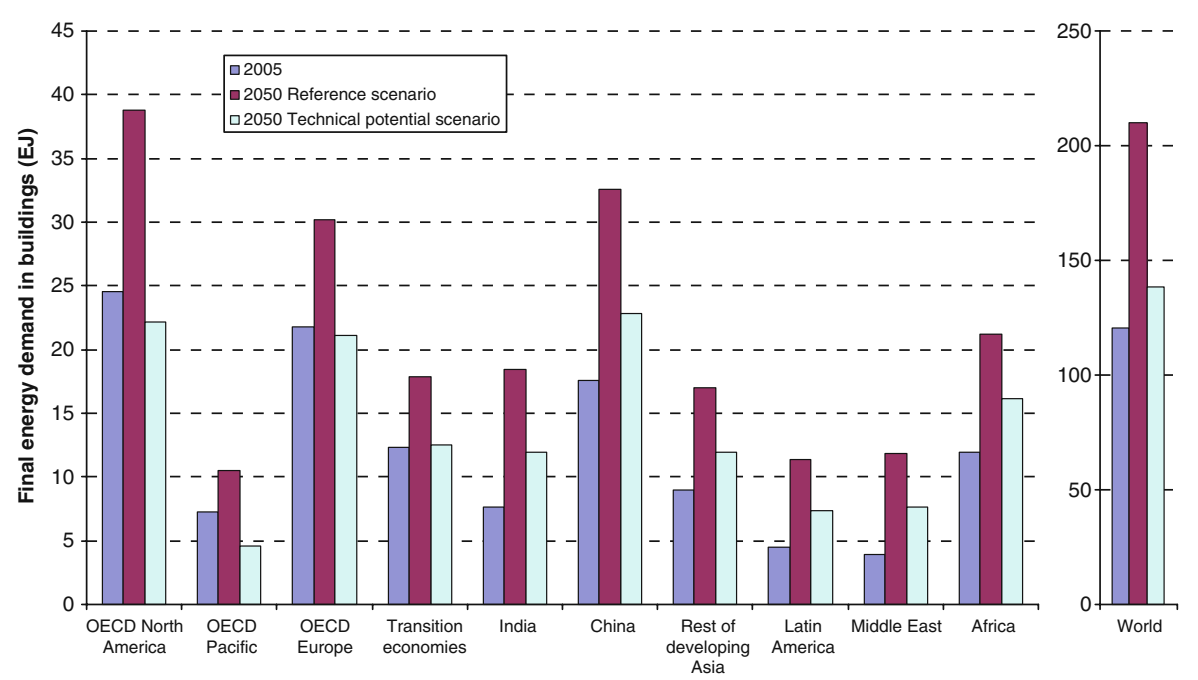

\section{Transformation sector}

Since power generation accounts for the largest share of losses in the transformation sector (70\% in 2005), we look at transformation losses in power generation in detail. For the remaining losses, we assume the same technical potential for energy efficiency improvement as in industries. It mainly involves oil refining 9\%, oil/gas extraction and coal mining $6 \%$, distribution losses $6 \%$ and iron and steel (blast furnaces and coke ovens) $6 \%$.

Figure 8 shows the fuel mix for power generation by region, based on electricity output in 2005 and 2050. In $2005,40 \%$ of global power generation is generated by coal, $7 \%$ by oil and $20 \%$ by natural gas. Nuclear power and hydropower correspond to $15 \%$ and $16 \%$ of power generation in 2005, respectively. By 2050, the fuel mix in the reference scenario is not expected to have changed much. By then, $70 \%$ of power is expected to be generated from fossil fuels, $9 \%$ by nuclear power and $21 \%$ by renewable energy sources. The fuel mix in 2050 is based on the development of the fuel mix in the World Energy Outlook in the period 2005-2030. For the technical potential scenario, we assume that the fuel mix for power generation in 2050 is the same as in the reference scenario (see also the "Discussion of uncertainties" section).

We focus primarily on the technical potential for improving the energy efficiency of fossil-fired power generation because $75 \%$ of losses in power generation occur in fossil-fired power generation and because it is of most concern for causing climate change and pollution.

The efficiency of fossil-fired power generation is calculated by the following formula: $E=\frac{P}{I}$

Where: $E=$ energy efficiency of power generation, $P=$ power production in region (based on gross output, including auxiliary electricity consumption) and $I=$ total fuel input for power generation in region (in lower heating value)

Currently, the global average conversion efficiency for fossil-fired power generation is 32\% for coal, $34 \%$ for gas and 34\% for oil in 2005 (IEA 2007a, b, c). The current best practice energy efficiency ${ }^{6}$ corresponds to $60 \%$ for gas-fired power generation, $50 \%$ for oil-fired power generation and $47 \%$ for coal-fired power generation (European Commission (2006a, b), Hendriks et al. (2004), VGB Powertech (2004), Graus and Worrell, 2009). Currently, a demonstration coal plant is being constructed in Europe with a steam temperature of $700^{\circ} \mathrm{C}$. The energy efficiency of this plant is expected to be in the range of $52 \%$ to $55 \%$. Commercial availability of the technology is expected after 2020 (Tech-wise A/S, 2003a).

We assume that the lifetime of a fossil power plant is 30-40 years, based on the lifetime of retired plants in the World Electric Power Plants Database (Platts, 2008). This means that by 2050 most power plants in

\footnotetext{
${ }^{6}$ Net design energy efficiency, auxiliary power consumption is excluded.
} 


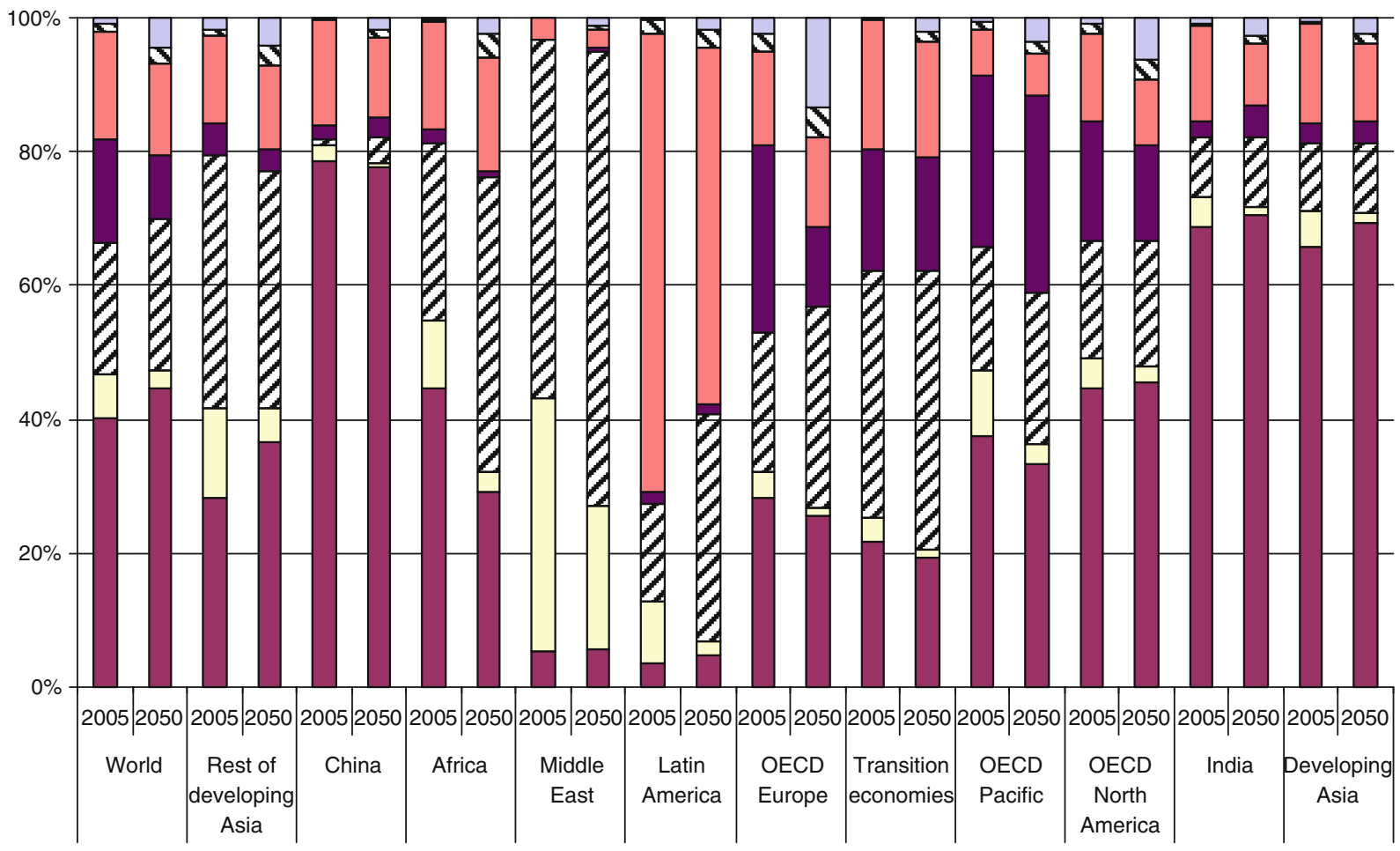

$\square$ Coal $\square$ Oil $\square$ Gas $\square$ Nuclear $\square$ Hydro $₫$ Biomass and waste $\square$ Other renewable

Fig. 8 Fuel mix for power generation based on electricity output (TWh)

operation today will have been replaced. We assume that by 2050 the energy efficiency of power plants can be $50 \%{ }^{7}$ for coal-fired plants, $50 \%$ for oil-fired plants and $60 \%$ for natural gas-fired plants. This corresponds to an average efficiency for fossil-fired power generation of $53 \%$ in 2050 , based on $64 \%$ coal-fired power generation, $33 \%$ gas-fired power generation and $4 \%$ oil-fired power generation, corresponding to the fossil fuel mix in the reference scenario in 2050. This is an improvement potential of $38 \%$ in the period $2010-2050$ and corresponds to $1.2 \%$ energy efficiency improvement per year.

The energy efficiency improvement potential differs per region and depends on the fuel mix for fossilfired power generation and the current energy efficiency. In most regions, coal and gas are the predominant source for fossil power generation. In the Middle East also, oil is used to a large extent of power generation ( $40 \%$ in 2005$)$.

\footnotetext{
${ }^{7}$ Assuming best practice for coal-fired power plants increases quite strongly in the next decade to $52-55 \%$.
}

Table 10 shows the average energy efficiency for fossil-fired power generation in 2005 and in 2050 based on realizing the technical potential. Also the energy efficiency improvement potential as percentage per year is shown.

For power generation by renewable sources and nuclear power, we assume an energy efficiency improvement potential of $0.35 \%$ per year, which corresponds to an improvement of $13 \%$ in the period 2010-2050. This is based on the potential for nuclear and hydro power generation, which produce the largest share of non-fossil power generation in the reference scenario. Existing older nuclear power plants have typical efficiencies of $33 \%$, whereas new nuclear power plants can reach efficiencies of $39 \%$ (Kloosterman 2006). This is an energy efficiency improvement of $15 \%$. We, theoretically, assume that all nuclear power plants in operation in 2005 will be replaced by 2050 by more efficient ones. The output of existing hydro power plants can be increased through retrofitting. Improvements in technology, design and used materials can result in increased 
Table 10 Average energy efficiency fossil-fired power generation in 2005 and 2050 and improvement potential per year

\begin{tabular}{lccc}
\hline & 2005 & 2050 & $\begin{array}{l}\text { Energy efficiency improvement } \\
\text { (\%/year) } 2010-2050\end{array}$ \\
\hline OECD Pacific & $41 \%$ & $53 \%$ & $0.6 \%$ \\
OECD Europe & $39 \%$ & $53 \%$ & $0.8 \%$ \\
OECD North America & $38 \%$ & $52 \%$ & $0.8 \%$ \\
Rest of developing Asia & $38 \%$ & $54 \%$ & $0.9 \%$ \\
Africa & $36 \%$ & $53 \%$ & $1.0 \%$ \\
Latin America & $36 \%$ & $55 \%$ & $1.1 \%$ \\
Middle East & $32 \%$ & $56 \%$ & $1.4 \%$ \\
China & $28 \%$ & $50 \%$ & $1.4 \%$ \\
India & $28 \%$ & $51 \%$ & $1.5 \%$ \\
Transition economies & $19 \%$ & $56 \%$ & $2.7 \%$ \\
World & $33 \%$ & $53 \%$ & $1.2 \%$ \\
\hline
\end{tabular}

efficiency and output, reduced losses, greater reliability and an extended service life. Alstrom (2002) reports an average increase of $12 \%$ in the output of large hydropower plants resulting from refurbishment in the USA. Based on these values, we come to an average efficiency improvement of $13 \%$ for non-fossil power generation in the period 2010-2050.

Summary Figure 9 shows the conversion efficiency for the transformation sector in 2005 and in 2050 per region, which in 2005 equals $68 \%$ globally and in $205081 \%$ (assuming the same fuel mix as in reference scenario).

Note that the energy efficiency improvement of power generation technologies will lead to a slight shift in the fuel input mix for power generation. The share of energy input in nuclear and hydro power plants increases somewhat in 2050 (from 12\% to $15 \%$ and from $6 \%$ to $7 \%$, respectively). The share of energy input in natural gas plants decreases somewhat (from $24 \%$ to $21 \%$ ), due to a higher energy efficiency improvement in gas-fired power plants than in nuclear and hydro plants.

\section{Results}

Based on the assumptions regarding technical potentials as described in the 'Approach and data sources' section, a technical potential scenario is calculated. In
Fig. 9 Conversion efficiency of transformation sector (ratio: final energy demand/primary energy demand)

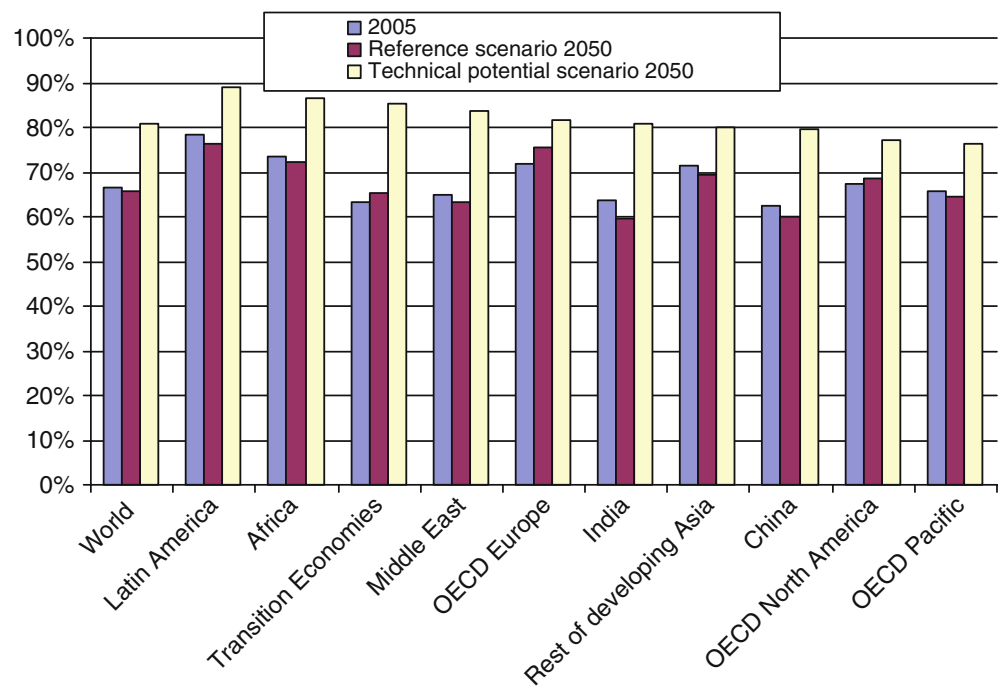


this scenario, final energy demand in 2050 is $44 \%$ below the level in the reference scenario; $317 \mathrm{EJ}$ instead of 571 EJ and 8\% above energy demand in 2005, which was 293 EJ. Primary energy supply is equal to $393 \mathrm{EJ}$ in 2050, which is $10 \%$ below energy supply in 2005, which was 439 EJ and 55\% lower than energy supply in the reference scenario in 2050 , which was 867 EJ.

Table 11 gives the increase or decrease of global energy demand in 2050 in comparison to 2005 per sector. Tables 16 and 17 in the Appendix give a breakdown of energy demand and supply by sector and region. Note that non-energy use (e.g. feedstocks in petrochemical industry) is excluded. The energy savings potential for the transformation sector is based on a theoretical approach, where the fuel mix for energy supply is assumed to be the same as in the reference scenario (see also the "Discussion of uncertainties" section).

Energy efficiency improvement in the transformation sector contributes to $19 \%$ of the total savings in primary energy supply in 2050, in comparison to reference primary energy supply. This shows that energy efficiency improvement in energy supply can play a significant role in global energy efficiency improvement. However, energy demand reduction should be a first priority since the energy demand sectors contribute to $81 \%$ of the total potential, first by direct energy demand reduction (54\%) and second by indirect energy savings due to reduced energy losses in the transformation sector (28\%).

The absolute savings by energy efficiency in the transformation sector depend on the level of energy demand. In this study, first energy savings for energy demand sectors are taken into account and then savings in the transformation sector. However, if no savings are made in energy demand, the absolute savings in the transformation sector would be $80 \%$ higher and correspond to $159 \mathrm{EJ}$ instead of $88 \mathrm{EJ}$.

Figure 10 shows the level of primary energy supply per region in 2005 and in 2050, for the reference scenario and the technical potential scenario. For the OECD countries and the region transition economies, the primary energy supply in 2050 is lower in the technical potential scenario than in 2005, whereas for the developing regions the primary energy supply in 2050 is higher than in 2005.

Figure 11 shows the final energy demand and primary energy supply in the period 2005-2050 in the

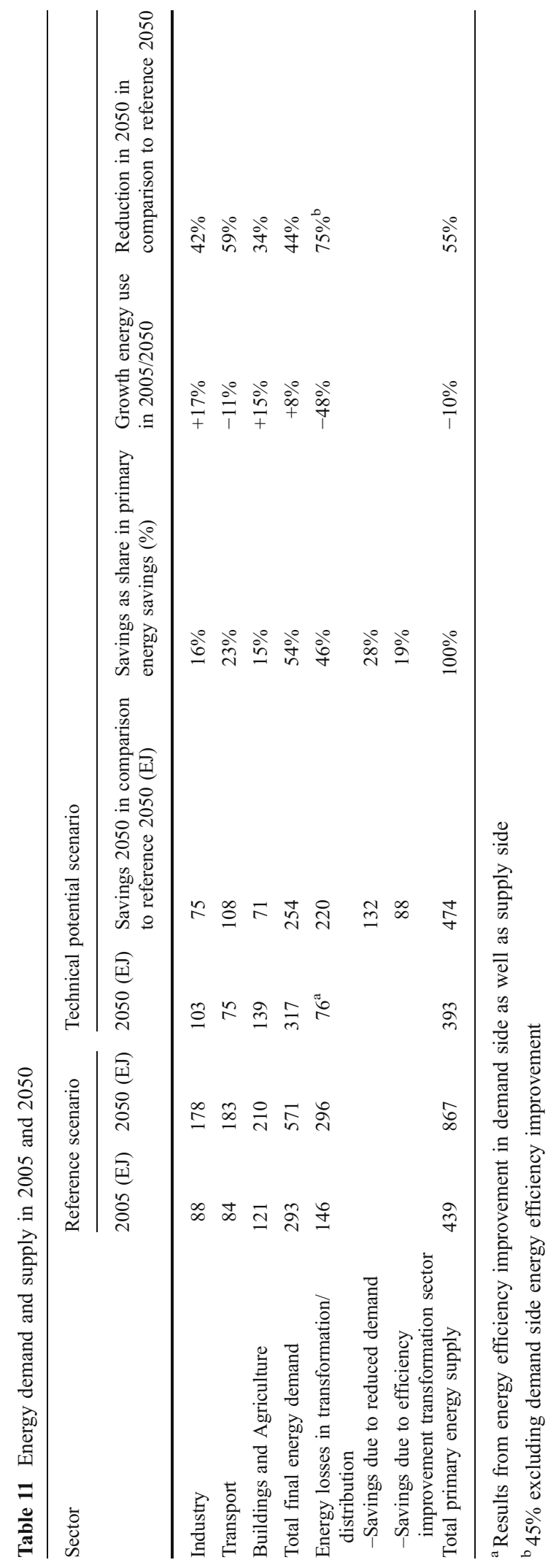


Fig. 10 Primary energy supply (PES) per region in reference scenario and technical potential scenario for 2005 and 2050
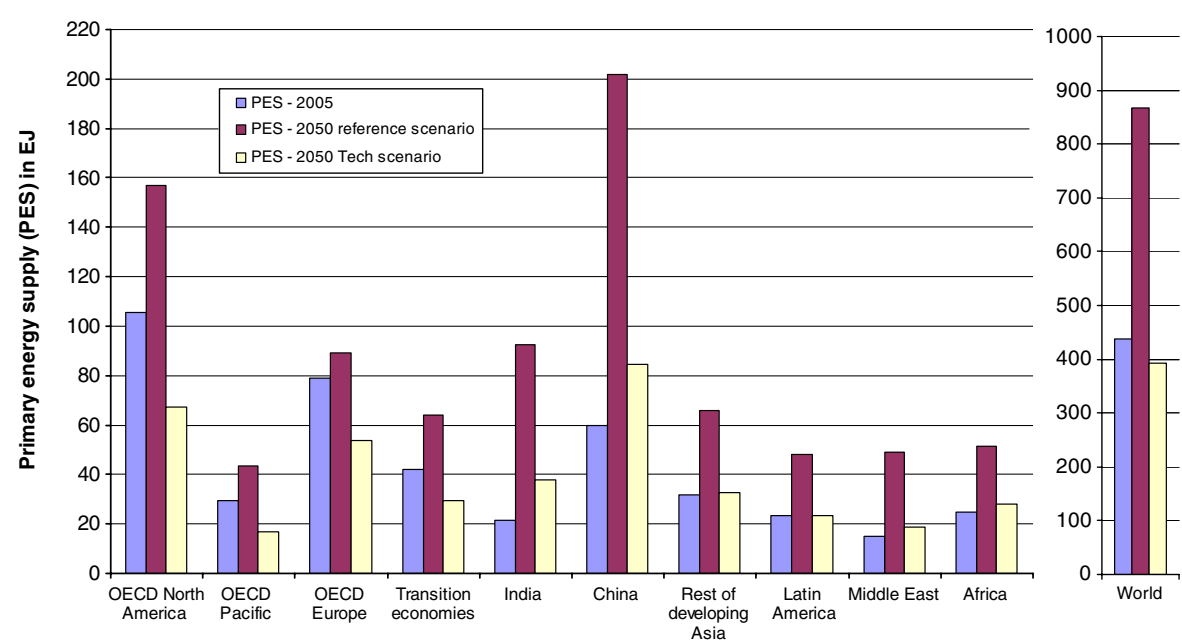

reference scenario and in the technical potential scenario.

Comparison to other studies The potential for reducing primary energy supply by implementing technical measures for energy efficiency improvement was calculated here to be $55 \%$ in comparison to the reference scenario, leading to a total primary energy supply of 393 EJ in 2050. As a comparison, most scenario assessment studies aimed at keeping global temperature increase below $2^{\circ} \mathrm{C}$ (based on models as GET, IMAGE, IMCP and MESSAGE) have primary energy supply levels of 400-600 EJ/year in 2050 (Hoogwijk and Hoehne 2005). Based on this analysis, these primary energy supply levels are technically feasible. A higher global temperature increase than $2{ }^{\circ} \mathrm{C}$, in comparison to pre-industrial level, is expected to have adverse effects (see, e.g. IPPC (2007) and Meinshausen et al. (2009).

Table 12 gives a summary of energy demand and GDP growth in comparison to the Greenpeace/EREC Energy [R]evolution scenario (Krewitt et al. 2009), the IEA BLUE Map scenario (IEA 2008a, b, c) and the EC WETO CC scenario (European Commission 2006b). Note that the energy demand projections in the Greenpeace/EREC Energy [r]evolution are partly based on the technical potentials as calculated in this paper. In the Energy [r]evolution study, it is assumed that a certain percentage of the technical potentials are implemented.

The IEA ETP BLUE MAP scenario (IEA 2008a, b, c) gives a potential of $33 \%$ of final energy demand that can be reduced in 2050 in comparison to baseline energy demand in 2050 , by implementing new far-reaching
Fig. 11 Global energy demand and supply in reference scenario and technical potential scenario

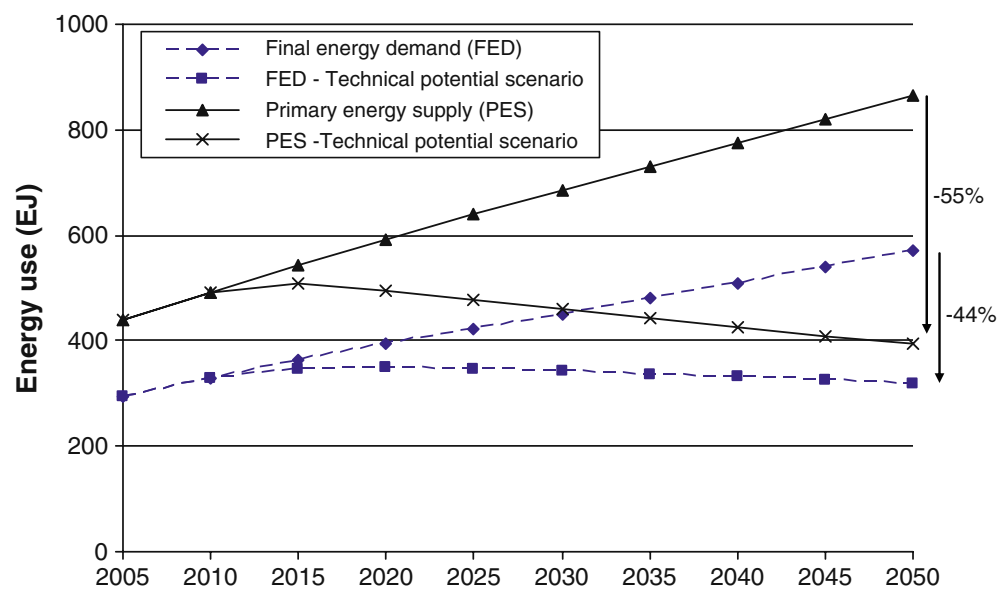


Table 12 Energy demand in scenarios up to 2050 (excluding non-energy use)

\begin{tabular}{|c|c|c|c|c|c|}
\hline & $\begin{array}{l}\text { Reference } \\
\text { scenario } \\
2050\end{array}$ & $\begin{array}{l}\text { Technical } \\
\text { potential } \\
\text { scenario }\end{array}$ & $\begin{array}{l}\text { Greenpeace/EREC } \\
(2008) \text { Energy } \\
{[R] \text { evolution }}\end{array}$ & $\begin{array}{l}\text { IEA BLUE } \\
\text { Map (2008) }\end{array}$ & $\begin{array}{l}\text { EC WETO } \\
\text { CCC }\end{array}$ \\
\hline Final energy demand in 2050 (EJ) & 571 & 317 & 350 & 431 & 498 \\
\hline GDP growth in period $2005-2050(\%)$ & $440 \%$ & $440 \%$ & $440 \%$ & $430 \%$ & $320 \%$ \\
\hline $\begin{array}{l}\text { Energy-intensity decrease (final energy } \\
\text { demand/GDP) in period 2005-2050 (\%/year) }\end{array}$ & 1.8 & 3.1 & 2.9 & 2.5 & 1.5 \\
\hline -Energy efficiency improvement $(\% / \text { year })^{\mathrm{a}}$ & 1.0 & 2.3 & 2.1 & 1.7 & \\
\hline -Structural change (\%/year) & 0.8 & 0.8 & 0.8 & 0.8 & \\
\hline Primary energy supply in 2050 (EJ) & 867 & 393 & 481 & $\sim 670$ & 813 \\
\hline $\begin{array}{l}\text { Conversion efficiency (ratio final energy } \\
\text { demand/primary energy supply) }\end{array}$ & $66 \%$ & $81 \%$ & $73 \%$ & $64 \%$ & $61 \%$ \\
\hline
\end{tabular}

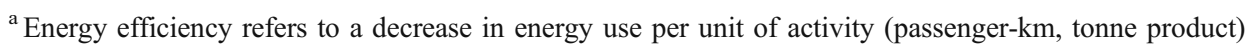

energy policies. This would correspond to an implementation of $75 \%$ of the technical potential as calculated here.

The difference in primary energy supply of the different scenarios is partly a result from the difference in conversion efficiency. The technical potential scenario and the Greenpeace/EREC scenario include a sharp reduction of losses in energy conversion and supply, while the IEA Blue Map and the EC WETO CCC scenario show a small decrease in conversion efficiency.

\section{Discussion of uncertainties}

The savings percentages are based on a number of different literature sources, ranging from sources that describe technological improvements in physical units (e.g. $\mathrm{GJ} / \mathrm{v}-\mathrm{km}$ ) to relative improvements in a certain time period. The savings potentials in the latter are based on assumptions regarding stock turnover that may not be compatible to the reference scenario used here. Also in some cases, studies are used that give a potential for a certain region that may not be applicable to another region. This leads to uncertainty in the results inherent to a study with a time horizon of 40 years. The study therefore merely aims to show the potentially important role energy efficiency can play in reducing greenhouse gas emissions.

Table 13 shows the main data concerns in this study by sector.
Other measures beside technical measures The calculations are based on technical measures, which are either already available or are expected to become available in the next decades. There is an additional potential to reduce energy demand by behavioural or organizational changes, such as a modal shift in transport from car to rail or different temperature/comfort setting in space heating, which is outside the scope of this study.

Carbon capture and storage The calculations for the supply side do not take into account the implementation of carbon capture and storage. The use of carbon capture and storage (CCS) at a power plant reduces the electric efficiency by $11-25 \%$ (Hendriks et al., 2004). Fuel input in fossil-fired power plants accounts for $15 \%$ of primary energy use in 2050 , in the technical potential scenario. If fuel input increases by $11-25 \%$, due to the capture of $\mathrm{CO}_{2}$, global primary energy use in 2050 would increase by a maximum of $1.7-3.8 \%$. In this case, all fossil power plants would be equipped with CCS.

Energy efficiency improvement for fossil power plants would decrease due to the application of CCS from $1.2 \%$ per year to $0.8 \%$ per year, in the technical potential scenario. In spite of the implementation of CCS, there is still energy efficiency improvement in fossil power plants because new best practice power plants have a significantly higher efficiency than current global averages. The situation per country however may be different. A country with already a high average fossil 
Table 13 Areas for data improvement by sector

\begin{tabular}{|c|c|}
\hline Sector & Areas for data improvement \\
\hline Industry & $\begin{array}{l}\text { Global estimates were used to calculate energy efficiency potentials for industry, because limited regional specific } \\
\text { data were available for this study. This could be improved by looking at national statistics and potential studies. }\end{array}$ \\
\hline Transport & $\begin{array}{l}\text { Detailed data regarding energy use in transport by region was available in IEA/SMP (2004). This source is } \\
\text { however quite old and data might have changed in the meantime so more recent sources would be preferred. }\end{array}$ \\
\hline $\begin{array}{l}\text { Buildings and } \\
\text { others }\end{array}$ & $\begin{array}{l}\text { In general there is a high uncertainty in data regarding energy use in buildings due to sector divergence. More } \\
\text { specifically, there was a lack of data for non-OECD countries regarding specific energy consumption of } \\
\text { dwellings. Furthermore, for all regions the potential for services sector was assumed to be the same as for } \\
\text { dwellings due to lack of data. }\end{array}$ \\
\hline $\begin{array}{l}\text { Transformation } \\
\text { sector }\end{array}$ & $\begin{array}{l}\text { For coal transformation and oil refineries the same energy efficiency potentials are assumed as for industries. } \\
\text { These estimates could be improved by using specific data for these sub sectors. For power generation, the main } \\
\text { focus was on fossil power generation. For renewable and nuclear power generation technologies few data on } \\
\text { energy efficiency improvement was available. These estimates could therefore be improved. }\end{array}$ \\
\hline
\end{tabular}

efficiency might decrease due to large scale CCS implementation.

If CCS is applied to all fossil power generation in the reference scenario, the conversion efficiency for the transformation sector would change from $81 \%$ to $79 \%$ in 2050 .

Rebound effect The rebound effect (see, e.g. Wei (2010) and Sorrel and Dimitropoulus (2008)) is not taken into account in this study. The savings achieved by implementing technical measures could be offset by higher use of energy services, e.g. if costs of using a certain energy service are reduced the demand for it could increase. The size of the effect is uncertain. Since the energy efficiency improvement here does not only involve cost-effective measures but also noncost-effective measures, it is not expected that the rebound effect would play a large role. Moreover, policy design can reduce the impact of the rebound effect.

Fuel mix energy supply The fuel mix of energy supply in the technical potential scenario is assumed to be the same as the fuel mix in the reference scenario. The energy savings in the technical potential scenario however can have an impact on the fuel mix used in the energy supply sector, e.g. due to higher savings in electric appliances than in heating of buildings. Furthermore, one would expect that in a case where strong energy efficiency improvement is encouraged, fuel mix changes from fossil fuels to other energy sources would also be stimulated. It was outside the scope of this study to look at fuel switches in the energy supply sector. A change in fuel mix could however influence energy efficiency of the transformation sector. An increase in the use of renewable energy sources would have a downward effect on primary energy supply because in IEA statistics the conversion efficiency from primary to final energy is $100 \%$ for wind, water and photovoltaics. Note that this is not the case for biomass, which has an energy efficiency below $100 \%$.

For transport, similarly, no changes in fuel mix are assumed. Some studies suggest however that changing to electric vehicles poses another energy efficiency improvement option. ECN (2009) estimates that electric cars can be $40 \%$ more efficient than gasoline or diesel cars. These savings are however counterbalanced by increased conversion losses in power generation. The potential for reducing primary energy supply by electrification of transport is therefore not expected to be large, unless renewable energy is used for power generation.

Recent trends This study was based on the IEA WEO 2007 edition. In the meantime, the 2009 edition is available (IEA, 2009). The 2009 edition has a lower global final energy demand in 2030 in comparison to the 2007 edition; $438 \mathrm{PJ}$ in comparison to $478 \mathrm{PJ}$ (including non-energy use). The difference is mainly caused by lower GDP growth rates due to the recent financial and economic crisis, leading to a $14 \%$ lower global GDP in 2030 in comparison to the 2007 edition. This lower GDP level in 2030 would have an 
effect on the energy use and related potentials in 2050. If we use the lower GDP growth rates for the period 2005-2030, primary energy supply in 2050 would be $794 \mathrm{EJ}$ in the reference scenario in comparison to $867 \mathrm{EJ}$ in the presented analysis. In the technical potential scenario, primary energy supply would then reduce from 393 EJ to $358 \mathrm{EJ}$ in 2050, assuming the same energy efficiency improvement potential of $55 \%$. Primary energy supply in 2050 would then be $19 \%$ below primary energy supply in 2005.

Stock turnover We assume that industrial sites that are currently in operation will have been replaced by 2050 by new more efficient ones, taking into account a typical lifetime of industrial sites of 30-40 years. However, there is a trend of extending lifetime of industrial plants by retrofitting parts of the site and thereby increase its use to more than $40-50$ years. In terms of energy efficiency improvement, this development is disadvantageous because the energy efficiency gain than can be reached by constructing a new site, where the design specifications are not limited by existing plant layout, is much higher than the energy efficiency gain that can be reached by retrofitting (part of) an existing site (Worrell and Biermans 2003). The potentials as calculated here can therefore only be achieved when the trend to extend lifetimes of industrial sites is discouraged.

Energy efficiency improvement in reference scenario It is assumed that autonomous energy efficiency improvement in the reference scenario is equal to $1 \%$ per year for industry and buildings, based on historical developments (see "Reference scenario" section). The precise underlying assumptions in the World Energy Outlook are however unknown. For transport, the energy efficiency improvement is based on the IEA/SMP transport model, where energy efficiency improvement is equal to $0.5 \%$ per year as global average. If we assume that this also applies to the buildings and industry sectors, global final energy demand would reduce to 268 EJ in 2050 (53\% reduction in comparison to baseline) and primary energy supply would decrease to $332 \mathrm{EJ}$ in 2050 (62\% reduction in comparison to baseline in 2050 and $24 \%$ reduction in comparison to 2005 level).
Combined heat and power generation The potential for energy efficiency improvement in the transformation sector is based on the fuel mix of the reference scenario. The option of increased use of combined heat and power generation to improve efficiency is not taken into account in this study. There may therefore be an additional potential for energy efficiency improvement by increasing the use of combined heat and power generation. Combined heat and power generation can increase the conversion efficiency in the transformation sector and can thereby reduce primary energy supply further. The contribution of combined heat and power generation (CHP) in energy supply depends on a number of factors such as remaining heat demand in end use sectors (industry and buildings) and the capacity of installed thermal power plants in 2050. IEA (2008b) estimates that the use of CHP can increase from $11 \%$ of electricity generation in 2005 to $24 \%$ of electricity generation in 2030 . This is a growth of $3.2 \%$ per year. If we assume that this growth rate is feasible until 2050, CHP plants would generate $45 \%$ of power generation in 2050. As a comparison, CHP plants in Denmark produce currently $52 \%$ of power generation (IEA 2008c). A share of $45 \%$ in power generation would means that $20 \%$ of heat demand in industry and buildings is fulfilled by CHP plants in 2050, assuming $40 \%$ power efficiency and $50 \%$ heat efficiency for CHP plants in 2050. Primary energy supply could then be further reduced by $7 \%$ in the technical potential scenario to $365 \mathrm{PJ}$.

\section{Conclusions}

Since greenhouse gas emissions from energy use account for around $75 \%$ of global greenhouse gas emissions, reducing energy use and greenhouse gas intensity of energy use is one of the most important targets of policies aimed at stabilizing greenhouse gas emissions. This study shows that energy efficiency improvement by implementing technical measures can play a large role in reducing greenhouse gas emissions from energy use. Under business as usual conditions, global energy supply is expected to nearly double by 2050 compared to 2005 . Technical energy efficiency measures can reduce energy supply by 2050 to $393 \mathrm{EJ}$, which is $55 \%$ below the reference level in 2050 (867 EJ) and 10\% below the 2005 level 
(432 EJ). This makes energy efficiency improvement a key part in any greenhouse gas abatement strategy, to be complemented by a decrease in greenhouse gas intensity of energy supply, by more renewable energy use or CCS. Reducing energy use, and more specifically reducing fossil fuel use, has a number of side benefits such as an increase in security of energy supply and a reduction of environmental concerns of fossil fuel use such as air pollution.

The largest share of the savings potential is found in the energy demand sectors. Energy efficiency improvement of energy demand leads to direct energy savings in the sector itself and to indirect energy savings by reduced transmission and distribution losses, together taking up $81 \%$ of estimated savings. Energy savings by improved energy efficiency in the transmission and distribution sectors are responsible for the remaining share of $19 \%$ savings.

Non-OECD countries show the largest growth of primary energy supply in the reference scenario ranging from a growth of $51 \%$ for transition economies to $190 \%$ for China and $330 \%$ for India, for the period 2005-2050. OECD countries show a lower growth of $26 \%$ for OECD Pacific, $33 \%$ for OECD Europe and $48 \%$ for OECD North America. In most non-OECD countries (except transition economies and Latin America), the energy efficiency improvement in the technical potential scenario is not sufficient to compensate for the growth in energy supply in the reference scenario. This means that even in the technical potential scenario primary energy supply in 2050 would grow by $13 \%$ in Africa, $23 \%$ in Middle East, $42 \%$ in China and $77 \%$ in India. In OECD countries on the other hand, energy supply would decrease by $43 \%$ for OECD Pacific, $32 \%$ for OECD Europe and $36 \%$ for OECD North America.

Acknowledgement This paper is based on different scenario studies for Greenpeace/EREC and UBA in cooperation with DLR. The views expressed in this paper do not necessarily reflect their views. A part of this paper was presented at the IAEE European Conference on 9 September 2009.

Open Access This article is distributed under the terms of the Creative Commons Attribution Noncommercial License which permits any noncommercial use, distribution, and reproduction in any medium, provided the original author(s) and source are credited.

\section{Appendix}

Table 14 Passenger and freight transport in passenger-km (p-km) and in tonne-km (t-km) in 2005 (IEA/SMP 2004)

\begin{tabular}{|c|c|c|c|c|c|c|c|c|c|c|c|}
\hline \multirow[t]{2}{*}{2005} & \multicolumn{7}{|l|}{$\mathrm{p}-\mathrm{km}$} & \multicolumn{4}{|l|}{$\mathrm{t}-\mathrm{km}$} \\
\hline & LDV & $\begin{array}{l}\text { Two } \\
\text { wheels }\end{array}$ & $\begin{array}{l}\text { Three } \\
\text { wheels }\end{array}$ & Buses & Minibuses & Pass rail & Air & $\begin{array}{l}\text { Medium } \\
\text { trucks }\end{array}$ & $\begin{array}{l}\text { Heavy } \\
\text { trucks }\end{array}$ & $\begin{array}{l}\text { Freight } \\
\text { Rail }\end{array}$ & $\begin{array}{l}\text { National } \\
\text { Marine }\end{array}$ \\
\hline $\begin{array}{l}\text { OECD North } \\
\text { America }\end{array}$ & $6.9 \mathrm{E}+12$ & $3.3 \mathrm{E}+10$ & $0.0 \mathrm{E}+00$ & $5.56 \mathrm{E}+11$ & $4.1 \mathrm{E}+10$ & $5.05 \mathrm{E}+10$ & $1.5 \mathrm{E}+12$ & $2.8 \mathrm{E}+11$ & $2.9 \mathrm{E}+12$ & $2.7 \mathrm{E}+12$ & $2.8 \mathrm{E}+11$ \\
\hline OECD Europe & $4.3 \mathrm{E}+12$ & $2.3 \mathrm{E}+11$ & $0.0 \mathrm{E}+00$ & $9.05 \mathrm{E}+11$ & $6.6 \mathrm{E}+10$ & $3.27 \mathrm{E}+11$ & $1.0 \mathrm{E}+12$ & $2.0 \mathrm{E}+11$ & $2.0 \mathrm{E}+12$ & $2.7 \mathrm{E}+11$ & $2.7 \mathrm{E}+11$ \\
\hline OECD Pacific & $1.5 \mathrm{E}+12$ & $1.5 \mathrm{E}+11$ & $0.0 \mathrm{E}+00$ & $6.85 \mathrm{E}+11$ & $8.6 \mathrm{E}+10$ & $2.56 \mathrm{E}+11$ & $3.7 \mathrm{E}+11$ & $1.3 \mathrm{E}+11$ & $3.1 \mathrm{E}+11$ & $1.6 \mathrm{E}+11$ & $1.3 \mathrm{E}+12$ \\
\hline $\begin{array}{l}\text { Transition } \\
\text { economies }\end{array}$ & $1.1 \mathrm{E}+12$ & $1.1 \mathrm{E}+11$ & $0.0 \mathrm{E}+00$ & $3.83 \mathrm{E}+11$ & $1.9 \mathrm{E}+11$ & $3.47 \mathrm{E}+11$ & $1.4 \mathrm{E}+11$ & $6.0 \mathrm{E}+10$ & $2.7 \mathrm{E}+11$ & $1.9 \mathrm{E}+12$ & $5.0 \mathrm{E}+10$ \\
\hline China & $4.3 \mathrm{E}+11$ & $5.1 \mathrm{E}+11$ & $1.5 \mathrm{E}+11$ & $5.61 \mathrm{E}+11$ & $6.6 \mathrm{E}+11$ & $5.41 \mathrm{E}+11$ & $2.0 \mathrm{E}+11$ & $7.3 \mathrm{E}+10$ & $2.2 \mathrm{E}+11$ & $1.6 \mathrm{E}+12$ & $2.5 \mathrm{E}+11$ \\
\hline $\begin{array}{l}\text { Rest of } \\
\text { developing } \\
\text { Asia }\end{array}$ & $4.2 \mathrm{E}+11$ & $6.8 \mathrm{E}+11$ & $1.4 \mathrm{E}+11$ & $1.05 \mathrm{E}+12$ & $7.9 \mathrm{E}+11$ & $9.90 \mathrm{E}+10$ & $2.5 \mathrm{E}+11$ & $1.2 \mathrm{E}+11$ & $6.8 \mathrm{E}+11$ & $3.4 \mathrm{E}+10$ & $1.2 \mathrm{E}+11$ \\
\hline India & $2.0 \mathrm{E}+11$ & $4.2 \mathrm{E}+11$ & $1.1 \mathrm{E}+11$ & $6.36 \mathrm{E}+11$ & $4.8 \mathrm{E}+11$ & $5.03 \mathrm{E}+11$ & $6.6 \mathrm{E}+10$ & $4.7 \mathrm{E}+10$ & $2.7 \mathrm{E}+11$ & $3.6 \mathrm{E}+11$ & $2.6 \mathrm{E}+10$ \\
\hline Middle East & $1.9 \mathrm{E}+11$ & $5.1 \mathrm{E}+10$ & $0.0 \mathrm{E}+00$ & $2.55 \mathrm{E}+11$ & $1.9 \mathrm{E}+11$ & $9.03 \mathrm{E}+10$ & $1.2 \mathrm{E}+11$ & $1.7 \mathrm{E}+11$ & $4.1 \mathrm{E}+11$ & $3.3 \mathrm{E}+10$ & $0.0 \mathrm{E}+00$ \\
\hline Latin America & $8.6 \mathrm{E}+11$ & $8.8 \mathrm{E}+10$ & $0.0 \mathrm{E}+00$ & $3.82 \mathrm{E}+11$ & $2.9 \mathrm{E}+11$ & $1.42 \mathrm{E}+10$ & $2.7 \mathrm{E}+11$ & $1.8 \mathrm{E}+11$ & $7.1 \mathrm{E}+11$ & $1.3 \mathrm{E}+11$ & $7.6 \mathrm{E}+10$ \\
\hline Africa & $3.4 \mathrm{E}+11$ & $7.1 \mathrm{E}+10$ & $0.0 \mathrm{E}+00$ & $4.33 \mathrm{E}+11$ & $5.1 \mathrm{E}+11$ & $1.98 \mathrm{E}+10$ & $9.8 \mathrm{E}+10$ & $3.8 \mathrm{E}+10$ & $1.5 \mathrm{E}+11$ & $1.3 \mathrm{E}+11$ & $1.4 \mathrm{E}+10$ \\
\hline $\begin{array}{l}\text { World Average } \\
\text { (stock-weighted) }\end{array}$ & $1.6 \mathrm{E}+13$ & $2.3 \mathrm{E}+12$ & $4.1 \mathrm{E}+11$ & $5.84 \mathrm{E}+12$ & $3.3 \mathrm{E}+12$ & $2.25 \mathrm{E}+12$ & & $1.3 \mathrm{E}+12$ & $7.9 \mathrm{E}+12$ & $7.3 \mathrm{E}+12$ & $2.4 \mathrm{E}+12$ \\
\hline
\end{tabular}


Table 15 Passenger and freight transport in passenger-km (p-km) and in tonne-km (t-km) in 2050 (IEA/SMP 2004)

\begin{tabular}{|c|c|c|c|c|c|c|c|c|c|c|c|}
\hline \multirow[t]{2}{*}{2050} & \multicolumn{7}{|l|}{$\mathrm{p}-\mathrm{km}$} & \multicolumn{4}{|l|}{$\mathrm{t}-\mathrm{km}$} \\
\hline & LDV & $\begin{array}{l}\text { Two } \\
\text { wheels }\end{array}$ & $\begin{array}{l}\text { Three } \\
\text { wheels }\end{array}$ & Buses & Minibuses & Pass rail & Air & $\begin{array}{l}\text { Medium } \\
\text { trucks }\end{array}$ & $\begin{array}{l}\text { Heavy } \\
\text { trucks }\end{array}$ & $\begin{array}{l}\text { Freight } \\
\text { Rail }\end{array}$ & $\begin{array}{l}\text { National } \\
\text { Marine }\end{array}$ \\
\hline $\begin{array}{l}\text { OECD North } \\
\text { America }\end{array}$ & $9.7 \mathrm{E}+12$ & $5.3 \mathrm{E}+10$ & $0.0 \mathrm{E}+00$ & $5.56 \mathrm{E}+11$ & $4.1 \mathrm{E}+10$ & $7.26 \mathrm{E}+10$ & $4.7 \mathrm{E}+12$ & $6.2 \mathrm{E}+11$ & $6.3 \mathrm{E}+12$ & $5.1 \mathrm{E}+12$ & $5.9 \mathrm{E}+11$ \\
\hline $\begin{array}{l}\text { OECD } \\
\text { Europe }\end{array}$ & $4.7 \mathrm{E}+12$ & $2.5 \mathrm{E}+11$ & $0.0 \mathrm{E}+00$ & $9.04 \mathrm{E}+11$ & $6.6 \mathrm{E}+10$ & $5.43 \mathrm{E}+11$ & $2.9 \mathrm{E}+12$ & $3.7 \mathrm{E}+11$ & $3.8 \mathrm{E}+12$ & $4.5 \mathrm{E}+11$ & $5.2 \mathrm{E}+11$ \\
\hline $\begin{array}{l}\text { OECD } \\
\text { Pacific }\end{array}$ & $1.7 \mathrm{E}+12$ & $1.7 \mathrm{E}+11$ & $0.0 \mathrm{E}+00$ & $6.84 \mathrm{E}+11$ & $8.5 \mathrm{E}+10$ & $4.62 \mathrm{E}+11$ & $1.0 \mathrm{E}+12$ & $2.9 \mathrm{E}+11$ & $6.9 \mathrm{E}+11$ & $2.8 \mathrm{E}+11$ & $2.8 \mathrm{E}+12$ \\
\hline $\begin{array}{l}\text { Transition } \\
\text { economies }\end{array}$ & $3.0 \mathrm{E}+12$ & $2.2 \mathrm{E}+11$ & $0.0 \mathrm{E}+00$ & $3.64 \mathrm{E}+11$ & $2.0 \mathrm{E}+11$ & $7.46 \mathrm{E}+11$ & $1.0 \mathrm{E}+12$ & $2.3 \mathrm{E}+11$ & $1.1 \mathrm{E}+12$ & $4.7 \mathrm{E}+12$ & $1.6 \mathrm{E}+11$ \\
\hline China & $5.3 \mathrm{E}+12$ & $1.4 \mathrm{E}+12$ & $1.4 \mathrm{E}+11$ & $5.34 \mathrm{E}+11$ & $6.9 \mathrm{E}+11$ & $1.91 \mathrm{E}+12$ & $1.6 \mathrm{E}+12$ & $4.7 \mathrm{E}+11$ & $1.4 \mathrm{E}+12$ & $6.1 \mathrm{E}+12$ & $1.0 \mathrm{E}+12$ \\
\hline $\begin{array}{l}\text { Rest of } \\
\text { developing } \\
\text { Asia }\end{array}$ & $3.0 \mathrm{E}+12$ & $1.6 \mathrm{E}+12$ & $1.3 \mathrm{E}+11$ & $9.98 \mathrm{E}+11$ & $8.2 \mathrm{E}+11$ & $2.80 \mathrm{E}+11$ & $1.6 \mathrm{E}+12$ & $6.0 \mathrm{E}+11$ & $3.4 \mathrm{E}+12$ & $8.0 \mathrm{E}+10$ & $4.1 \mathrm{E}+11$ \\
\hline India & $2.1 \mathrm{E}+12$ & $1.4 \mathrm{E}+12$ & $9.8 \mathrm{E}+10$ & $6.06 \mathrm{E}+11$ & $5.0 \mathrm{E}+11$ & $1.62 \mathrm{E}+12$ & $5.8 \mathrm{E}+11$ & $3.1 \mathrm{E}+11$ & $1.8 \mathrm{E}+12$ & $1.4 \mathrm{E}+12$ & $1.1 \mathrm{E}+11$ \\
\hline Middle East & $7.7 \mathrm{E}+11$ & $1.3 \mathrm{E}+11$ & $0.0 \mathrm{E}+00$ & $2.42 \mathrm{E}+11$ & $2.0 \mathrm{E}+11$ & $2.40 \mathrm{E}+11$ & $5.0 \mathrm{E}+11$ & $5.0 \mathrm{E}+11$ & $1.2 \mathrm{E}+12$ & $7.5 \mathrm{E}+10$ & $0.0 \mathrm{E}+00$ \\
\hline $\begin{array}{l}\text { Latin } \\
\text { America }\end{array}$ & $3.8 \mathrm{E}+12$ & $2.9 \mathrm{E}+11$ & $0.0 \mathrm{E}+00$ & $3.63 \mathrm{E}+11$ & $3.0 \mathrm{E}+11$ & $2.09 \mathrm{E}+10$ & $2.2 \mathrm{E}+12$ & $6.5 \mathrm{E}+11$ & $2.6 \mathrm{E}+12$ & $2.4 \mathrm{E}+11$ & $2.3 \mathrm{E}+11$ \\
\hline Africa & $1.8 \mathrm{E}+12$ & $3.9 \mathrm{E}+11$ & $0.0 \mathrm{E}+00$ & $4.12 \mathrm{E}+11$ & $5.3 \mathrm{E}+11$ & $5.39 \mathrm{E}+10$ & $7.0 \mathrm{E}+11$ & $1.7 \mathrm{E}+11$ & $6.9 \mathrm{E}+11$ & $3.8 \mathrm{E}+11$ & $4.8 \mathrm{E}+10$ \\
\hline $\begin{array}{l}\text { World Average } \\
\text { (stock-weighted) }\end{array}$ & $3.6 \mathrm{E}+13$ & $5.9 \mathrm{E}+12$ & $3.7 \mathrm{E}+11$ & $5.66 \mathrm{E}+12$ & $3.4 \mathrm{E}+12$ & $5.95 \mathrm{E}+12$ & $1.7 \mathrm{E}+13$ & $4.2 \mathrm{E}+12$ & $2.3 \mathrm{E}+13$ & $1.9 \mathrm{E}+13$ & $5.9 \mathrm{E}+12$ \\
\hline
\end{tabular}

Table 16 Final energy demand and primary energy supply by region in 2005 and 2050

\begin{tabular}{|c|c|c|c|c|c|c|}
\hline & \multicolumn{3}{|c|}{ Final energy demand (FED) } & \multicolumn{3}{|c|}{ Primary energy supply (PES) } \\
\hline & \multicolumn{2}{|c|}{ Reference scenario } & \multirow{2}{*}{$\begin{array}{l}\text { Technical potential } \\
\text { scenario } \\
2050(\text { EJ) }\end{array}$} & \multicolumn{2}{|c|}{ Reference scenario } & \multirow{2}{*}{$\begin{array}{l}\text { Technical potentia } \\
\text { scenario } \\
2050(\text { EJ) }\end{array}$} \\
\hline & 2005 (EJ) & 2050 (EJ) & & 2005 (EJ) & $2050(\mathrm{EJ})$ & \\
\hline World & 293 & 571 & 316 & 439 & 867 & 392 \\
\hline $\begin{array}{l}\text { OECD North } \\
\text { America }\end{array}$ & 71 & 107 & 52 & 106 & 157 & 67 \\
\hline OECD Pacific & 21 & 28 & 14 & 29 & 37 & 17 \\
\hline OECD Europe & 52 & 68 & 41 & 79 & 105 & 53 \\
\hline $\begin{array}{l}\text { Transition } \\
\text { economies }\end{array}$ & 27 & 42 & 25 & 42 & 64 & 29 \\
\hline India & 13 & 55 & 30 & 21 & 92 & 38 \\
\hline China & 43 & 121 & 68 & 60 & 174 & 85 \\
\hline $\begin{array}{l}\text { Rest of } \\
\text { developing } \\
\text { Asia }\end{array}$ & 20 & 46 & 27 & 32 & 77 & 33 \\
\hline Latin America & 15 & 37 & 20 & 23 & 58 & 24 \\
\hline Middle East & 12 & 31 & 17 & 15 & 40 & 19 \\
\hline Africa & 18 & 37 & 24 & 25 & 51 & 28 \\
\hline
\end{tabular}


Table 17 Final energy demand by sector and region in 2005 and 2050

\begin{tabular}{|c|c|c|c|c|c|c|c|c|c|}
\hline & \multicolumn{3}{|l|}{ Industry } & \multicolumn{3}{|l|}{ Transport } & \multicolumn{3}{|c|}{ Buildings and others } \\
\hline & \multicolumn{2}{|l|}{$\begin{array}{l}\text { Reference } \\
\text { scenario }\end{array}$} & \multirow{2}{*}{$\begin{array}{l}\text { Technical } \\
\text { potential } \\
\text { scenario } \\
2050(\text { EJ) }\end{array}$} & \multicolumn{2}{|l|}{$\begin{array}{l}\text { Reference } \\
\text { scenario }\end{array}$} & \multirow{2}{*}{$\begin{array}{l}\text { Technical } \\
\text { potential } \\
\text { scenario } \\
2050(\mathrm{EJ})\end{array}$} & \multicolumn{2}{|l|}{$\begin{array}{l}\text { Reference } \\
\text { scenario }\end{array}$} & \multirow{2}{*}{$\begin{array}{l}\text { Technical } \\
\text { potential } \\
\text { scenario } \\
2050(\mathrm{EJ})\end{array}$} \\
\hline & $2005(\mathrm{EJ})$ & $2050(\mathrm{EJ})$ & & $2005(\mathrm{EJ})$ & $2050(\mathrm{EJ})$ & & $2005(\mathrm{EJ})$ & $2050(\mathrm{EJ})$ & \\
\hline World & 88 & 178 & 103 & 84 & 183 & 75 & 121 & 210 & 138 \\
\hline $\begin{array}{l}\text { OECD North } \\
\text { America }\end{array}$ & 16 & 21 & 13 & 31 & 47 & 17 & 25 & 39 & 22 \\
\hline OECD Pacific & 7 & 9 & 6 & 7 & 9 & 3 & 7 & 11 & 5 \\
\hline OECD Europe & 14 & 17 & 11 & 16 & 20 & 9 & 22 & 30 & 21 \\
\hline $\begin{array}{l}\text { Transition } \\
\text { economies }\end{array}$ & 9 & 14 & 9 & 6 & 10 & 4 & 12 & 18 & 13 \\
\hline India & 4 & 20 & 11 & 2 & 16 & 7 & 8 & 18 & 12 \\
\hline China & 20 & 52 & 29 & 5 & 36 & 16 & 18 & 33 & 23 \\
\hline $\begin{array}{l}\text { Rest of developing } \\
\text { Asia }\end{array}$ & 6 & 14 & 8 & 5 & 15 & 7 & 9 & 17 & 12 \\
\hline Latin America & 6 & 13 & 8 & 5 & 12 & 5 & 4 & 11 & 7 \\
\hline Middle East & 4 & 11 & 6 & 4 & 8 & 3 & 4 & 12 & 8 \\
\hline Africa & 3 & 6 & 4 & 3 & 10 & 4 & 12 & 21 & 16 \\
\hline
\end{tabular}

\section{References}

ACEEE (American Council for an Energy-Efficient Economy). (2007). Consumer Guide to Home Energy Savings Cooling Equipment. http://www.aceee.org/consumer guide/cooling.htm\#reduce.

Akerman, J. (2005). Sustainable air transport - on track in 2050. Transportation Research. Part D, 10, 111-125.

Alstrom. (2002). Retrofit of hydropower plants. www.alstrom.com.

Austrian Energy Agency. (2006). Keep cool-local and individual adaptation. http://www.energyagency.at/publ/ pdf/keepcool_adaptation.pdf.

Bertoldi, P., \& Atanasiu, B. (2006). Electricity consumption and efficiency trends in the enlarged European Union-Status Report 2006. Institute for Environment and Sustainability.

Blok, K. (2005). Improving energy-efficiency by five percent and more per year? Journal of Industrial Ecology, 8(4), 87-99.

DeCicco, J., An, F., Ross, M. (2001). Technology options for improving the fuel economy of U.S. cars and light trucks by 2010-2015. American Council for an Energy Efficient Economy, Washington, D.C http://www.aceee.org/pubs/t012.htm.

ECN. (2009). Duurzame innovatie in wegverkeer. Een evaluatie van vier transitiepaden voor het thema Duurzame Mobiliteit. http://www.ecn.nl/publicaties/default.aspx?nr=ECN-E-08076.

Elliott, R.N., T. Langer, S. Nadel. Jan 2006. Reducing Oil Use Through Energy Efficiency: Opportunities Beyond Cars and Light Trucks. American Council for an Energy Efficient Economy (ACEEE). http://www.aceee.org/pubs/e061.htm.

ENCI. (2002). Energy data for cement production. Maastricht: ENCI.
Enviroharvest. (2008). Heat recovery. http://www.enviroharvest. ca/heat_recovery.htm.

European Aluminium Association. (2008). http://www.eaa.net/ en/about-aluminium/recycling/.

European Commission. (2005). Doing more with less-green paper energy-efficiency. European Communities. http://ec. europa.eu/energy/efficiency/index_en.htm.

European Commission. (2006a). Reference document on best available techniques for large combustion plants. Brussels.

European Commission. (2006b). World energy technology outlook-2050. WETO-H2. Brussels: European Commission.

EuroTopten. (2008a). Best products of Europe. Energy consumption and saving potentials. http://www.topten.info/index. php?page=energy_consumption_and_saving_potentials.

EuroTopten (2008b). Best Products of Europe. Computer monitors. http://www.topten.info/english/office_equipment/ computer monitors/17 inch.html.

Fulton, L. \& Eads G. (2004). IEA/SMP Model Documentation and Reference Case Projection. IEA, Paris, France

Graus, W., \& Worrell, E. (2009). Trend in efficiency and capacity of fossil power generation in the EU. Energy Policy, 37, 2147-2160.

Harmelink M., Blok, K., Chang, M., Graus, W., Joosen, S. (2005). Options to speed up energy savings in the Netherlands (Mogelijkheden voor versnelling van energiebesparing in Nederland). Ecofys, Utrecht, Netherlands.

Hekkert, M.P., Joosten, L.A.J., Worrell, E. (1998). Material efficiency improvement for European packaging in the period 2000-2020. in Factor 2/Factor 10. Utrecht.

Hendriks, C., Harmelink, M., Burges, K., Ramsel, K. (2004). Power and heat production: plant developments and grid losses. Ecofys, Utrecht, Netherlands. 
Hoogwijk, M. A., \& Hoehne, N. (2005). Comparison of scenarios for keeping global temperature increase below $2^{\circ} \mathrm{C}$. Utrecht: Ecofys.

IEA. (2006). Energy technology perspectives 2006-scenarios and strategies to 2050. Paris: International Energy Agency.

IEA. (2007a). World energy outlook 2007 edition. Paris: International Energy Agency (IEA).

IEA. (2007b). Energy balances of OECD countries 1960-2005 and energy balances of non-OECD countries 1971-2005. Paris: International Energy Agency (IEA).

IEA. (2007c). Energy use in the new millennium - trends in IEA Countries. Paris: International Energy Agency.

IEA. (2008a). Energy technology perspectives 2008-scenarios and strategies to 2050. Paris: International Energy Agency.

IEA. (2008b). Global CHP/DHC Potential. International Energy Agency, Paris, France. http://www.iea.org/G8/CHP/global potential.asp.

IEA. (2008c). The role of CHP in delivering global energy \& environmental solutions. International Energy Agency, Paris, France. http://www.iea.org/speech/2008/tk_chp.pdf.

IEA. (2009). World energy outlook 2009 edition. Paris: International Energy Agency (IEA).

IEA/SMP. (2004). IEA/SMP model documentation and reference case projection. L. Fulton (IEA) and G. Eads (CRA) for WBCSD's Sustainable Mobility Project (SMP), July 2004.

International Aluminium Institute. (2008). Aluminium statistics. London, UK. http://www.world-aluminium.org/iai/stats/.

IPPC. (2007). Fourth assessment report of the intergovernmental panel on climate change. Geneva.

Joosen et al. (2002). Sectoral objectives of emission reduction. Assignment for European Commission. http://ec.europa. eu/environment/enveco/climate change/pdf/top down analysis_xsum.pdf.

Kloosterman. (2006). Overzicht van nieuwe kerncentrales. Netherlands: TU Delft.

Krewitt, W., Simon, S., Graus, W., Teske, S., Zervos, A., \& Schäfer, O. (2007). The $2^{\circ} \mathrm{C}$ scenario-a sustainable world energy perspective. Energy Policy, 35(2007), 49694980.

Krewitt, W., Teske, S., Simon, S., Pregger, T., Graus, W., Blomen, E., et al. (2009). Energy [R]evolution 2008-a sustainable world energy perspective. Energy Policy, 37 (12), 5764-5775.

LEDs Magazine. (2007). http://www.ledsmagazine.com/news/ $4 / 1 / 23$.

Lensink, S.M., \& de Wilde, H. (2007). Kostenefficientie van (technische) opties voor zuiniger vrachtverkeer. Energy research Centre of The Netherlands (ECN). http://www. ecn.nl/docs/library/report/2007/e07003.pdf.

Meier, A. (2001). A worldwide review of standby power in homes. Lawrence Berkeley National Laboratory, University of California.

Meier, A., Lin, J., Liu, J., Li, T. (2004). Standby power use in Chinese homes. Energy and Buildings 36, pp. 1211-1216.

Meinshausen, M., Meinshausen, N., Hare, W., Raper, S., Frieler, K., Knutti, R., et al. (2009). Greenhouse-gas emission targets for limiting global warming to $2^{\circ} \mathrm{C}$. Nature, 458, 1158-1162.
Neelis, M., \& Patel, M. (2006). Long-term production, energy consumption and $\mathrm{CO}_{2}$ emission scenarios for the worldwide iron and steel industry. Utrecht University.

ODYSSEE. (2005). Energy efficiency indicators database. France: ENERDATA.

Philips. (2010). LED monitor, WXGA 19 inch E-line. http:// www.consumer.philips.com/c/pc-monitoren/wxga-met-19inch-e-line-en-18.5-inch-scherm-191el1sb 00/prd/nl/nl/.

Phylipsen, G.J.M. (2000). International Comparisons \& National Commitments, Analysing energy and technology differences in the climate debate, $\mathrm{PhD}$ thesis, april 2000, Utrecht University. Utrecht, The Netherlands.

Platts. (2008). World Electric Power Plant Database (WEPP). United States. http://www.platts.com/infostore/product info.php?products id $=85$.

REEEP. (2008). Glob̄al energy efficiency status report. Netherlands: Ecofys.

Schäfer, A., \& Jacoby, H. D. (2006). Vehicle technology under $\mathrm{CO} 2$ constraint: a general equilibrium analysis. Energy Policy, 34(9), 975-985.

Simon, S., Krewitt, W., Pregger, T. (2008). Energy [R]evolution scenario 2008. Working Paper on specification of world regions, population development and GDP development. DLR, Institute of Technical Thermodynamics Systems Analysis and Technology Assessment. Stuttgart.

Sinton, J.E., Lewis, J.I., Price, L.K., Worrell, E. (2002). China's sustainable energy future scenarios and carbon emissions analysis. Subreport 11: international trends in energyefficiency technologies and policies. LBNL, Berkeley, US.

Smokers, R., Vermeulen, R., van Mieghem, R., Gense, R., Skinner, I., Fergusson, M., MacKay, E., ten Brink, P., Fontaras, G., Samaras, Z. (2006). Review and analysis of the reduction potential and costs of technological and other measures to reduce $\mathrm{CO} 2$-emissions from passenger cars. TNO, IEEP and LAT on behalf of the European Commission (DG-ENTR) http://www.lowcvp.org.uk/ assets/reports/TNO $\% 20$ IEEP $\% 20$ LAT $\% 20$ et $\% 20 \mathrm{al} \%$ 20report_co2_reduction.pdf.

Sorrel, S., \& Dimitropoulus, J. (2008). The rebound effect: microeconomic definitions, limitations and extensions. Ecological Economics, 65(3), 636-649.

SRU (German Advisory Council on the Environment). (2005). Reducing $\mathrm{CO} 2$ emissions from cars. Section from the Special Report Environment and Road Transport. www. lowcvp.org.uk/assets/reports/Reducing_CO2_Emissions \% 20Aug\%2005.pdf.

Tech-wise A/S (2003a). http://ad700.techwise.dk/annual1999.htm. Toyota. (2010). http://data.toyota.nl/home/data/ToyotaV8/pdf/ Auris_fullhybrid_psb.pdf, http://www.toyota.com.au/prius.

UBA. (2010). Role and potential of renewable energy and energy efficiency for global energy supply. By DLR/ Ecofys/Wuppertal Institute. Commissioned by Ministry of Environment, Germany.

UK MTP (United Kingdom Market Transformation Programme). (2008). BNXS15: Standby power consumption-domestic appliances. http://www.mtprog.com/ApprovedBriefing Notes/PDF/MTP_BNXS15 2008February11.pdf.

UNECE (United Nations Economic Commission for Europe). (2008). Human Settlement Database. http://w3.unece.org/ stat/HumanSettlements.asp. 
Ürge-Vorsatz, D., \& Novikova, A. (2008). Potentials and costs of carbon dioxide mitigation in the world's buildings. Energy Policy, 36, 642-661.

US DOE EERE (United States Department of Energy; Energyefficiency and Renewable Energy). (2008). Inventions \& innovationprojectfactsheet.highenergy-efficiencyairconditioning. http://www1.eere.energy.gov/inventions/pdfs/nimitz.pdf.

US EPA (United States Environmental Protection Agency). (2007). Cool roofs. http://www.epa.gov/heatisld/strategies/ coolroofs.html.

US FEMP (United States Federal Energy Management Program). (2007). How to buy products with low standby power. http://www1.eere.energy.gov/femp/procurement/ eep_standby power.html.

USGS. (2008). Aluminium production. US Geological Survey. Reston, USA. http://minerals.usgs.gov/minerals/pubs/ commodity/aluminum/myb1-2006-alumi.xls.

Van Laar, P. A. (1993). Het specifiek energiegebruik van transportmodaliteiten. Rapport No. 91.3.TT.2909. Faculteit der Werktuigbouwkunde en Maritieme Techniek, Vakgroep Transporttechnologie, Technische Universiteit Delft.

VGB Powertech. (2004). Jahresnutzungsgrad von fossil befeuerten Kraftwerken gemäß den "besten verfügbaren Kraftwerkstechniken”. VGB Stellungnahme. August 2004
Waide, P. (2007). Presentation of light's labour's lost: policies for energy-efficient lighting. OECD/IEA, 2007, Paris, France.

WBCSD. (2005). Pathways to 2050 - energy and climate change. World Business Council on Sustainable Development, Switzerland. http:/www.wbcsd.org/plugins/ DocSearch/details.asp?type=DocDet\&ObjectId=MTczNzA.

Wei, T. (2010). A general equilibrium view of global rebound effects. Energy Economics, 32(3), 661-672.

World Aluminium. (2008). http://www.world-aluminium.org/ iai/stats/March2008.

Worrell, E., \& Biermans, G. (2003). Move over! Stock turnover, retrofit and industrial energy efficiency. Energy Policy., 33(7), 949-962.

Worrell, E., Faaij, A. P. C., Phylipsen, G. J. M., \& Blok, K. (1995). An approach for analysing the potential for material. Efficiency Improvement Resources, Conservation \& Recycling, 3/4(13), 215-232.

Worrell, E., Price, L., Neelis, M., Galitsky, C., Zhou Nan (2008). World best practice energy intensity values for selected industrial sectors. Lawrence Berkeley National Laboratory (LBNL). Berkeley, United States.

WRI. (2008). Climate analysis indicators tool (CAIT). http:// cait.wri.org/. 